\title{
Seasonal Changes and Spatial Variation in Water Quality of a Large Young Tropical Reservoir and Its Downstream River
}

\author{
Teck-Yee Ling, ${ }^{1}$ Norliza Gerunsin, ${ }^{2}$ Chen-Lin Soo, ${ }^{1}$ Lee Nyanti, ${ }^{1}$ \\ Siong-Fong Sim, ${ }^{1}$ and Jongkar Grinang ${ }^{3}$ \\ ${ }^{1}$ Faculty of Resource Science and Technology, Universiti Malaysia Sarawak, 94300 Kota Samarahan, Sarawak, Malaysia \\ ${ }^{2}$ Universiti Teknologi MARA, Kota Samarahan Campus, Jalan Meranek, 94300 Kota Samarahan, Sarawak, Malaysia \\ ${ }^{3}$ Institute of Biodiversity and Environmental Conservation, Universiti Malaysia Sarawak, 94300 Kota Samarahan, Sarawak, Malaysia \\ Correspondence should be addressed to Teck-Yee Ling; teckyee60@gmail.com
}

Received 18 January 2017; Revised 18 May 2017; Accepted 19 June 2017; Published 26 July 2017

Academic Editor: Wenshan Guo

Copyright (C) 2017 Teck-Yee Ling et al. This is an open access article distributed under the Creative Commons Attribution License, which permits unrestricted use, distribution, and reproduction in any medium, provided the original work is properly cited.

\begin{abstract}
This study examined the water quality of the large young tropical Bakun hydroelectric reservoir in Sarawak, Malaysia, and the influence of the outflow on the downstream river during wet and dry seasons. Water quality was determined at five stations in the reservoir at three different depths and one downstream station. The results show that seasons impacted the water quality of the Bakun Reservoir, particularly in the deeper water column. Significantly lower turbidity, SRP, and TP were found during the wet season. At 3-6 m, the oxygen content fell below $5 \mathrm{mg} / \mathrm{L}$ and hypoxia was also recorded. Low $\mathrm{NO}_{2}{ }^{-}-\mathrm{N}, \mathrm{NO}_{3}{ }^{-}-\mathrm{N}$, and SRP and high $\mathrm{BOD}_{5}, \mathrm{OKN}$, and TP were observed in the reservoir indicating organic pollution. Active logging activities and the dam construction upstream resulted in water quality deterioration. The outflow decreased the temperature, $\mathrm{DO}$, and $\mathrm{pH}$ and increased the turbidity and TSS downstream. Elevated organic matter and nutrients downstream are attributable to domestic discharge along the river. This study shows that the downstream river was affected by the discharge through the turbines, the spillway operations, and domestic waste. Therefore, all these factors should be taken into consideration in the downstream river management for the health of the aquatic organisms.
\end{abstract}

\section{Introduction}

The creation of a large-scale dam and its associated reservoir often has significant negative impacts on the hydrological, biological, and chemical processes of the reservoir, upstream, and downstream of the dam [1-9]. The Bakun hydroelectric dam, which was impounded from 2010 to 2012 on the Balui River in Malaysia, produced these effects. The dam which is one of the tallest concrete rock filled dams $(205 \mathrm{~m})$ in the world created a reservoir covering a surface area of $695 \mathrm{~km}^{2}$. A few pre- and postimpoundment studies on the physicochemical parameters of the Bakun Dam reservoir have been performed [10-12]. However, the reservoir water quality is likely changing as the reservoir is receiving loads of pollutants from adjacent anthropogenic activities during its operation $[13,14]$. Water quality deterioration is a common problem in reservoirs surrounded with anthropogenic activities receiving high loads of suspended solids, organic matter, and nutrients $[15,16]$.

The water quality of reservoirs has been observed to vary seasonally in tandem with changes in temperature and rainfall [17-19]. The low and high precipitation during dry and wet seasons in a tropical country like Malaysia can greatly change the water quality of the reservoir. The high precipitation during the wet season can either decrease the pollutant concentration by dilution or deteriorate the reservoir water quality due to increased surface runoff from anthropogenic activities. Reference [20] demonstrated that the levels of total phosphorus in Batang Ai Reservoir during the rainy season and high water levels were lower than those observed during the dry season and low water levels. Besides, high volume of inflow following heavy rainfall promotes mixing and disturbs stratification in the reservoir. The increase of bottom 


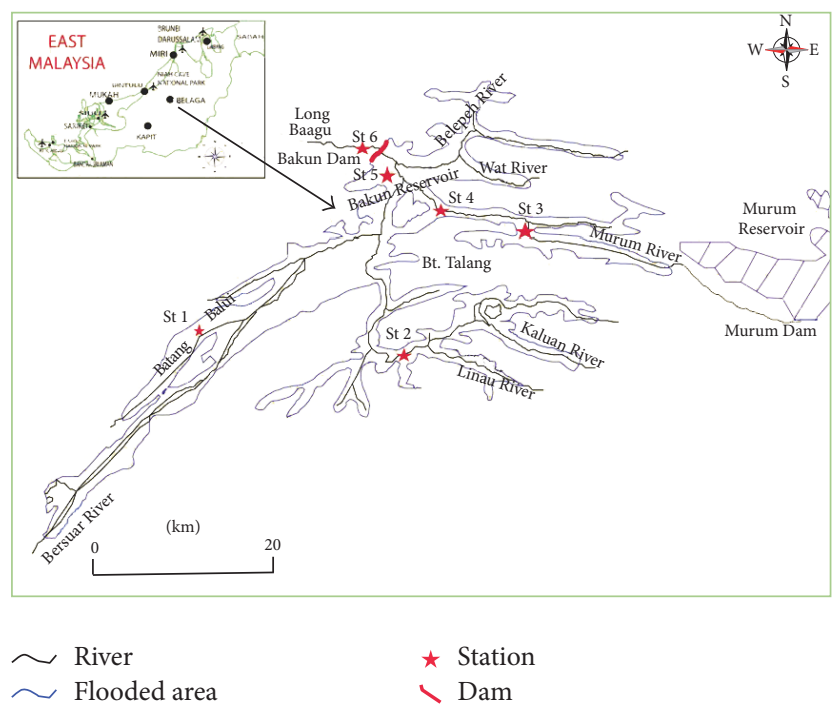

FIGURE 1: The study area and sampling stations in the present study.

dissolved oxygen level in the well-mixed reservoir inhibits the release of nutrients from sediments causing a rapid reduction of phytoplankton concentration in the reservoir [17].

On the other hand, the reservoir outflow has a great influence on the downstream river. Studies have shown that the downstream river is subjected to major environmental impacts which range from downstream morphology changes to loss of biodiversity of the ecosystem $[1,5,7,8,21]$. The reservoir outflow is often controlled by the electrical demand and operation cost, independent of ecological considerations in the downstream river. Differences in structure and operation scheme of a dam may result in differences in water quality downstream. Recently, [22] demonstrated that the physicochemical characteristics of the river downstream of the Bakun Dam changed when the spillway was opened.

As a young reservoir in a tropical country, changes continue to occur in the reservoir and it is important to monitor the water quality in order to evaluate its suitability for secondary purposes such as aquaculture and recreation. The knowledge of the seasonal variation of the reservoir's water quality is important for dam operation and management decision. The impact of the dam on the water quality of its downstream river during the wet and dry seasons remains unknown. Hence, the aim of this study was to assess the water quality of the Bakun Reservoir and the influence of its outflow on the water quality of the downstream river during wet and dry seasons.

\section{Materials and Methods}

2.1. Study Area and Sampling Stations. The present study was conducted at Bakun Reservoir and its downstream river in Sarawak, Malaysia, as illustrated in Figure 1. The Bakun hydroelectric dam was built across the Batang Balui with a total of eight installed turbines and a spillway weir located at $209 \mathrm{~m}$ above sea level. The reservoir covers mainly the Balui River that is fed by three major tributaries, namely, the Murum River, Linau River, and Bahau River. A total of five stations were selected at the Bakun Reservoir and one station was selected at the downstream river. Stations 1 and 2 were located at the Batang Balui and Linau River, respectively. Stations 3 and 4 were located at the Murum River where the upstream Murum hydroelectric dam was under ongoing construction during the time of sampling. Station 5 was located in the proximity of the Bakun hydroelectric dam and downstream of active logging activities while Station 6 was located at the downstream river approximately $4.3 \mathrm{~km}$ from the dam.

Sampling was conducted in February and September 2014 corresponding to the wet and dry seasons in Sarawak (Table 1). There was no rain recorded during the two and three weeks prior to the first and second samplings, respectively. The water level during the second sampling in the dry season was approximately $7 \mathrm{~m}$ lower than the water level during the wet season. The water release during hydropower generation is drawn from the top $10 \mathrm{~m}$ of the reservoir using selective withdrawal intake structures. Occasionally, additional water is released from the spillway with intake at a depth of approximately $15 \mathrm{~m}$. At the end of the spillway, the water hits the concrete barrier before entering Balui River downstream. Sampling was conducted during electrical power generation where the downstream river received the water discharged from the reservoir after the water passed through the turbines. During the first sampling, additional water was discharged from the spillway at a rate of $501 \mathrm{~m}^{3} / \mathrm{s}$ in addition to the turbine outflow $\left(536 \mathrm{~m}^{3} / \mathrm{s}\right)$. The spillway was closed during the second sampling; hence, Station 6 was receiving solely the turbine outflow at a rate of $730 \mathrm{~m}^{3} / \mathrm{s}$.

2.2. Field Collection and Laboratory Analysis. Depth profiles of temperature and dissolved oxygen (DO) were measured using a YSI $6820 \mathrm{~V} 2$ multiparameter water quality sonde during the first sampling in February 2014. The $\mathrm{pH}$ and turbidity were measured at $0 \mathrm{~m}, 10 \mathrm{~m}$, and $20 \mathrm{~m}$ depths in Bakun Reservoir in both samplings by using a pH meter (EcoScan, Eutech) and a turbidity meter (Martini Instruments, Mi415), respectively. Triplicate water samples were collected at $0 \mathrm{~m}$, $10 \mathrm{~m}$, and $20 \mathrm{~m}$ depths in Bakun Reservoir (Stations 1 to 5) using a Van Dorn water sampler whereas triplicate water samples were collected at $0 \mathrm{~m}$ depth at the downstream river of the dam (Station 6). The depth of the reservoir was measured using a portable depth sounder (Speedtech). All sampling bottles were acid-washed, cleaned, and dried before use. Water samples were acidified to $\mathrm{pH}<2$ for total phosphorus (TP) analysis. All samples were placed in an ice box and transported to the laboratory for further analysis [23].

All the analyses were conducted according to standard methods $[23,24]$. Chlorophyll $a(\mathrm{Chl} a)$ was determined from adequate samples filtered through $0.45 \mu \mathrm{m}$ glass fiber filter (Whatman GF/F) and extracted for $24 \mathrm{~h}$ using $90 \%$ $(\mathrm{v} / \mathrm{v})$ acetone. The absorbance was read using a DR 2800 spectrophotometer and concentration of $\mathrm{Chl} a$ was calculated according to [25]. Total suspended solid (TSS) was calculated as the difference between the initial and final weights of the 
TABLE 1: The details of the sampling location and sampling regime in the present study.

\begin{tabular}{|c|c|c|c|}
\hline Station & Coordinates & Date & Location \\
\hline \multicolumn{4}{|c|}{ Bakun hydroelectric reservoir } \\
\hline St. 1 & $\begin{array}{l}\mathrm{N} 02^{\circ} 43^{\prime} 34.4^{\prime \prime} \\
\mathrm{E} 114^{\circ} 01^{\prime} 44.2^{\prime \prime}\end{array}$ & $\begin{array}{l}26 \text { Feb. 2014, 1:15 p.m. } \\
24 \text { Sept. 2014, 8:15 a.m. }\end{array}$ & $\begin{array}{l}\text { Batang Balui } \\
\text { Sunny during both sampling trips }\end{array}$ \\
\hline St. 2 & $\begin{array}{l}\mathrm{N} 02^{\circ} 39^{\prime} 32.2^{\prime \prime} \\
\mathrm{E} 114^{\circ} 03^{\prime} 29.5^{\prime \prime}\end{array}$ & $\begin{array}{l}26 \text { Feb. 2014, 9:45 a.m. } \\
24 \text { Sept. 2014, 10:45 a.m. }\end{array}$ & $\begin{array}{l}\text { Linau River } \\
\text { Sunny during both sampling trips }\end{array}$ \\
\hline St. 3 & $\begin{array}{l}\mathrm{N} 02^{\circ} 42^{\prime} 59.8^{\prime \prime} \\
\mathrm{E} 114^{\circ} 09^{\prime} 43.8^{\prime \prime}\end{array}$ & $\begin{array}{l}27 \text { Feb. 2014, 12:55 p.m. } \\
25 \text { Sept. 2014, 9:51 a.m. }\end{array}$ & $\begin{array}{c}\text { Upper part of Murum River } \\
\text { Sunny during both sampling trips } \\
\text { Soil erosion was observed in the upper Murum River bank }\end{array}$ \\
\hline St. 4 & $\begin{array}{l}\mathrm{N} 02^{\circ} 44^{\prime} 15.3^{\prime \prime} \\
\mathrm{E} 114^{\circ} 05^{\prime} 16.6^{\prime \prime}\end{array}$ & $\begin{array}{l}26 \text { Feb. 2014, 3:06 p.m. } \\
24 \text { Sept. 2014, 1:42 p.m. }\end{array}$ & $\begin{array}{l}\text { Lower part of Murum River } \\
\text { Sunny during both sampling trips }\end{array}$ \\
\hline St. 5 & $\begin{array}{l}\mathrm{N} 02^{\circ} 45^{\prime} 09.8^{\prime \prime} \\
\mathrm{E} 114^{\circ} 02^{\prime} 32.9^{\prime \prime}\end{array}$ & $\begin{array}{l}27 \text { Feb. 2014, 3:00 p.m. } \\
25 \text { Sept. 2014, 2:08 p.m. }\end{array}$ & $\begin{array}{l}\text { Near the intake point and the dam } \\
\text { Cloudy during both sampling trips }\end{array}$ \\
\hline \multicolumn{4}{|c|}{ Downstream river of Bakun hydroelectric dam } \\
\hline St. 6 & $\begin{array}{l}\mathrm{N} 02^{\circ} 46^{\prime} 21.8^{\prime \prime} \\
\mathrm{E} 114^{\circ} 01^{\prime} 41.6^{\prime \prime}\end{array}$ & $\begin{array}{l}26 \text { Feb. } 2014,3: 00 \text { p.m. } \\
24 \text { Sept. } 2014,1: 35 \text { pm }\end{array}$ & $\begin{array}{c}\text { Long Baagu ( } 4.3 \mathrm{~km} \text { downstream of the Bakun hydroelectric dam) } \\
\text { Sunny during both sampling trips }\end{array}$ \\
\hline
\end{tabular}

$0.45 \mu \mathrm{m}$ glass fiber filter (Whatman GF/F), after filtration of an adequate sample volume and drying at $105^{\circ} \mathrm{C}$. Fiveday biochemical oxygen demand $\left(\mathrm{BOD}_{5}\right)$ was determined as the difference between the initial and five-day DO content, after five-day-long incubation of the sample. The initial DO content was determined in the field and increased by vigorous aeration if the $\mathrm{DO}$ value was low. $\mathrm{NO}_{2}{ }^{-}-\mathrm{N}$ and $\mathrm{NO}_{3}{ }^{-}-\mathrm{N}$ levels were determined by the diazotization method (low range) and the cadmium reduction method, respectively, after filtering through a $0.45 \mu \mathrm{m}$ glass fiber filter (Whatman GF/F). Organic Kjeldahl nitrogen (OKN) was determined by the Macro-Kjeldahl Method where ammonia was removed from the water sample before digestion and distillation, followed by Nessler's method. SRP was determined by the colorimetric ascorbic acid method after filtering through a $0.45 \mu \mathrm{m}$ glass fiber filter (Whatman GF/F). TP was determined by the ascorbic acid method after persulfate digestion of samples. The estimated detection limits of $\mathrm{NO}_{2}{ }^{-}-\mathrm{N}, \mathrm{NO}_{3}{ }^{-}-\mathrm{N}$, and SRP were $0.005 \mathrm{mg} / \mathrm{L} \mathrm{NO}_{2}{ }^{-}-\mathrm{N}, 0.01 \mathrm{mg} / \mathrm{L} \mathrm{NO}_{3}{ }^{-}-\mathrm{N}$, and $0.02 \mathrm{mg} / \mathrm{L}$ $\mathrm{PO}_{4}{ }^{3-}$, respectively.

Quality control steps were taken throughout the study. Sample bottles and glassware were washed using phosphatefree detergent followed by the standard acid wash procedure. Sample preparation and storage were performed according to the standard methods [23]. Triplicate blank water that was free of the analytes of interest was used in the same procedure for each of the aforementioned analyses.

2.3. Statistical Analysis. Comparison of water quality parameters between the stations and the depths in the Bakun hydroelectric reservoir was conducted using one-way ANOVA and Tukey's pairwise comparisons with 5\% significance level. Student's $t$-test was used to compare the water quality of the reservoir between the wet and dry seasons. Pearson's correlation analysis was performed to determine the relationship among all the parameters in the reservoir during each season. The water quality of the downstream river between the wet and dry seasons and the results between the intake point of the dam and the downstream river were compared using Student's $t$-test. Cluster analysis (CA) was used to investigate the grouping of the sampling stations with different depths by using the water quality parameters collected in the reservoir and the downstream river. $Z$-score standardization of the variables and Ward's method using Euclidean distances as a measure of similarity were used. All the statistical analyses were carried out by using the Statistical Package for the Social Sciences (SPSS Version 22, SPSS Inc., 1995).

\section{Results and Discussion}

3.1. Water Quality of Bakun Reservoir. Figure 2 illustrates the vertical stratification in Bakun Reservoir, indicating poor water mixing in the reservoir. Among the five sampling stations in the Bakun Reservoir, Station 2, which is located at Linau River, is stratified into three distinct layers of different temperatures. The thermocline layer observed at $3 \mathrm{~m}$ to $7 \mathrm{~m}$ separates the epilimnion $\left(\approx 30.5^{\circ} \mathrm{C}\right)$ and hypolimnion $\left(\approx 25.5^{\circ} \mathrm{C}\right)$ at Station 2 . Similarly, $[10,11]$ reported that the thermocline started at a depth of 4-5 $\mathrm{m}$ and between $6 \mathrm{~m}$ and $9 \mathrm{~m}$ in Bakun Reservoir during the filling phase and 13 months after reaching the full-supply level, respectively. Thermal stratification in reservoirs has been widely reported in tropical and subtropical reservoirs [19, 26-28]. The temperature gradient within the thermocline layer in the Bakun Reservoir is in agreement with the range of thermal stratification of $0.5^{\circ} \mathrm{C}$ to $5^{\circ} \mathrm{C}$ for a tropical reservoir [29].

Dissolved oxygen was relatively consistent in the surface water of the Bakun Reservoir, with a mean value of $7.22 \mathrm{mg} / \mathrm{L}$. The DO level started to decrease rapidly from a depth of $2 \mathrm{~m}$ to less than $0.2 \mathrm{mg} / \mathrm{L}$ at a depth of $4 \mathrm{~m}$ at Station 1 which is located at Batang Balui. The DO level at Stations 2,3 , and 5 started to decrease rapidly from the depth of around $3 \mathrm{~m}$ whereas the DO level at Station 4 started to decrease from $5 \mathrm{~m}$ depth. In other words, the healthy level of DO content above $5 \mathrm{mg} / \mathrm{L}$ was only observed at the water column above 3-6m in Bakun Reservoir. Similarly, [26] 

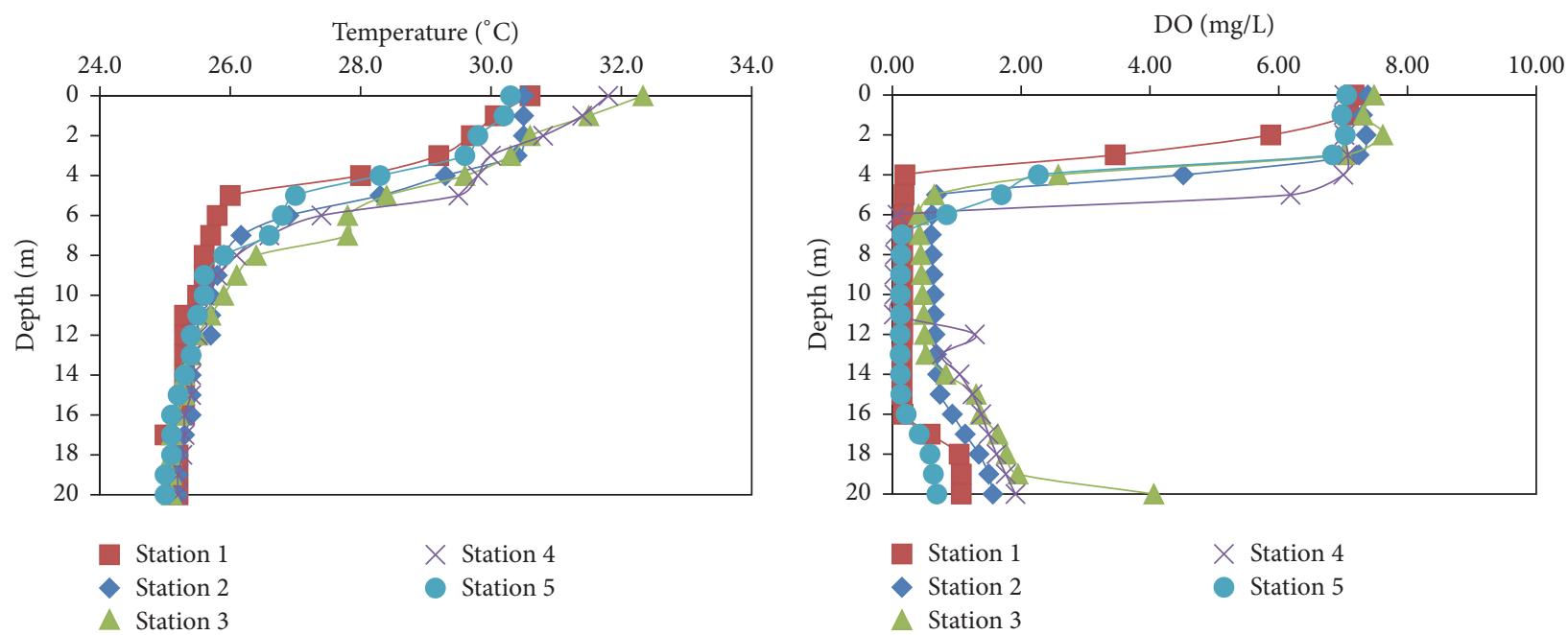

FIGURE 2: Depth profile of temperature and DO in Bakun Reservoir in February 2014.

showed that oxygen depletion is a common phenomenon in the hypolimnia of Indonesian lakes and reservoirs with different oxycline depths. The authors attributed the shallow oxycline depth and thick anoxic layer in the Cirata Reservoir to the weak wind-induced mixing and high organic loads that lead to rapid decomposition and oxygen depletion in the reservoir. On the other hand, the DO concentration never fell below $2 \mathrm{mg} / \mathrm{L}$ in Qiandaohu Lake, China, where the DO depth profiles were closely linked to the water temperature depth profiles [19]. The decrease of DO with depth is commonly observed in reservoirs as photosynthesis increases oxygen level in the surface water while respiration of bacteria decomposing dead organic matter consumes all the dissolved oxygen in the bottom water column coupled with insufficient exchange with oxygenated surface water [30]. However, a slight increase of DO content was observed at the water column of the Bakun Reservoir between $12 \mathrm{~m}$ and $20 \mathrm{~m}$ which is most likely due to the additional water discharged from the spillway where the water intake was at a depth of approximately $15 \mathrm{~m}$. The rapid water movement due to the additional water withdrawal at the particular water column promotes the mixing of the low DO water with a large volume of oxygenated colder water inflow from tributaries around the reservoir [14]. This phenomenon was not observed in the study in [11] where the DO content was reported as undetectable from a depth of $7 \mathrm{~m}$ up to a depth of $30 \mathrm{~m}$ as the reservoir water was not discharged from the spillway during this study.

The $\mathrm{pH}$ value of the Bakun Reservoir ranged from $4.93 \pm$ 0.06 to $8.06 \pm 0.05$ during the wet season with the lowest and highest $\mathrm{pH}$ value being observed at Station 5 and Station 2, respectively. On the other hand, the $\mathrm{pH}$ value of the Bakun Reservoir is relatively consistent during the dry season with a mean value of 7.30. Vertical distribution of $\mathrm{pH}$ values in Bakun Reservoir differed between the wet and dry seasons although this was not significantly different ( $p$ value $>0.05$ ) (Table 2). During the dry season, the $\mathrm{pH}$ value of the Bakun Reservoir decreased as depth increased up to a depth of
$10 \mathrm{~m}$ and remained at a similar value up to a depth of $20 \mathrm{~m}$ as illustrated in Figure 3. The vertical distribution of $\mathrm{pH}$ values during the dry season in the present study is in good agreement with the previous study in the Bakun Reservoir [11] and the Batang Ai Reservoir [31] where the $\mathrm{pH}$ value of the reservoir water decreased as depth increased. However, the $\mathrm{pH}$ value tends to increase with depth when the surface $\mathrm{pH}$ value is low as demonstrated by Stations 3 and 5 during the wet season. The results showed that the low $\mathrm{pH}$ value at the surface water was diluted by the reservoir water with higher $\mathrm{pH}$ value as depth increased. The dilution in the water column improved the $\mathrm{pH}$ at Station 3 from 6.3 to 6.8. However, despite the dilution in the water column, Station 5 , which was the closest station to the dam, still showed $\mathrm{pH}$ values of less than $6.5 \mathrm{mg} / \mathrm{L}$. On the other hand, when the $\mathrm{pH}$ value was high $(>7)$, the $\mathrm{pH}$ value decreased as depth increased which is similar to vertical $\mathrm{pH}$ distribution during the dry season. The surface $\mathrm{pH}$ value was classified as Class I but was changed to Class II as depth increased according to the National Water Quality Standard (NWQS) for Malaysia [32] during the dry season. During the wet season, the $\mathrm{pH}$ values of the Bakun Reservoir were classified as Class I except for Stations 3 and 5. The surface water at Station 3 was classified as Class II while the extremely low surface $\mathrm{pH}$ value of 4.9 at Station 5 exceeded the NWQS. Besides, the pH values at Station 5 at depths of $10 \mathrm{~m}$ and $20 \mathrm{~m}$ were classified as Classes II and III, respectively.

Table 3 shows that no significant correlation ( $p$ value $>$ 0.05 ) was found between the $\mathrm{pH}$ value of the Bakun Reservoir and the other parameters during the wet season suggesting that the $\mathrm{pH}$ value of the Bakun Reservoir, particularly Stations 3 and 5 , was mainly influenced by the low $\mathrm{pH}$ surface runoff from the anthropogenic activities in the surrounding area. Stations 3 and 5 were located downstream of the construction site of the Murum hydroelectric dam and active logging activities. The decomposition of organic matter derived from anthropogenic activity acidified the upstream rivers that flow into the reservoir and caused the acidification at the stations. 


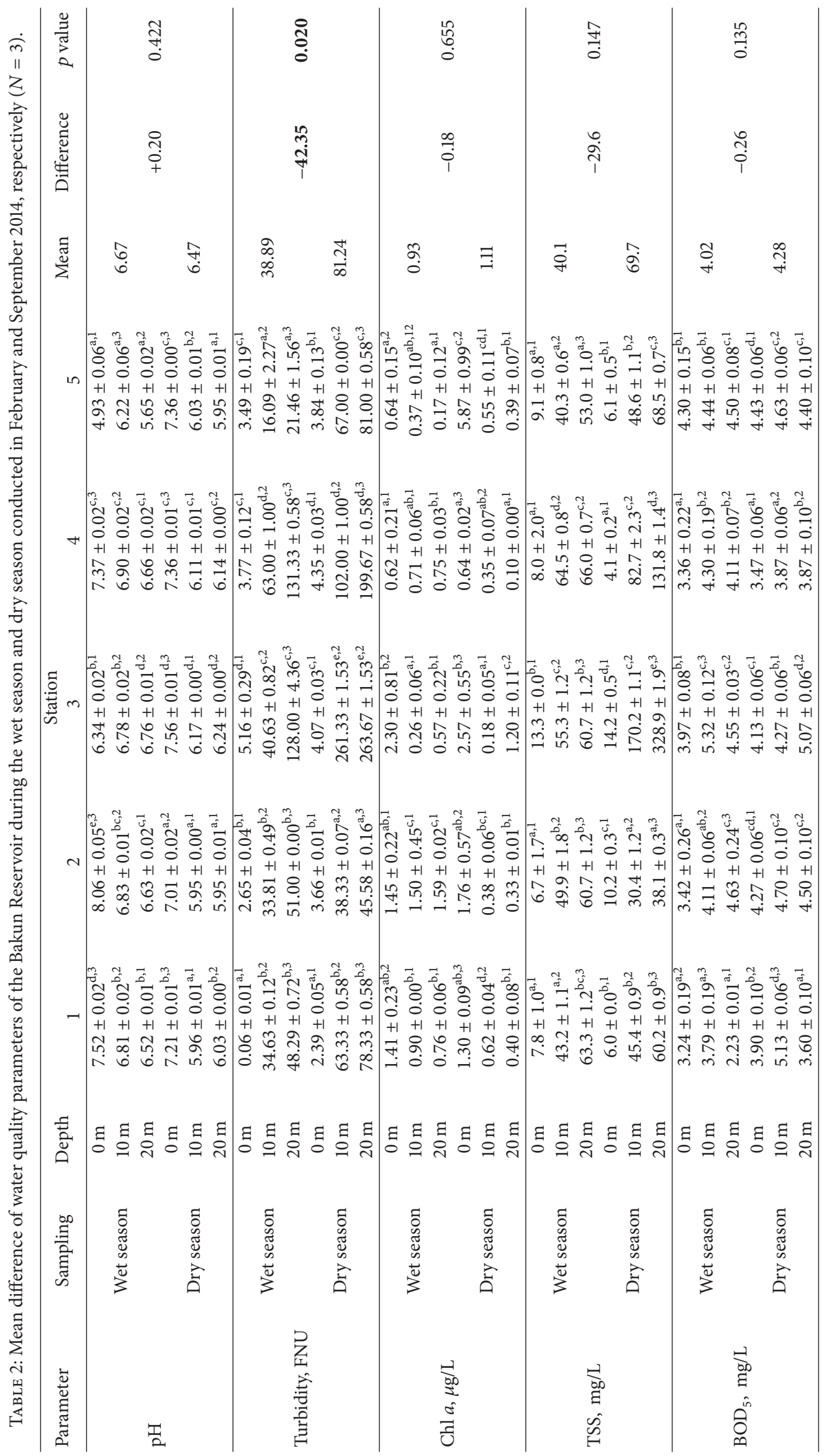




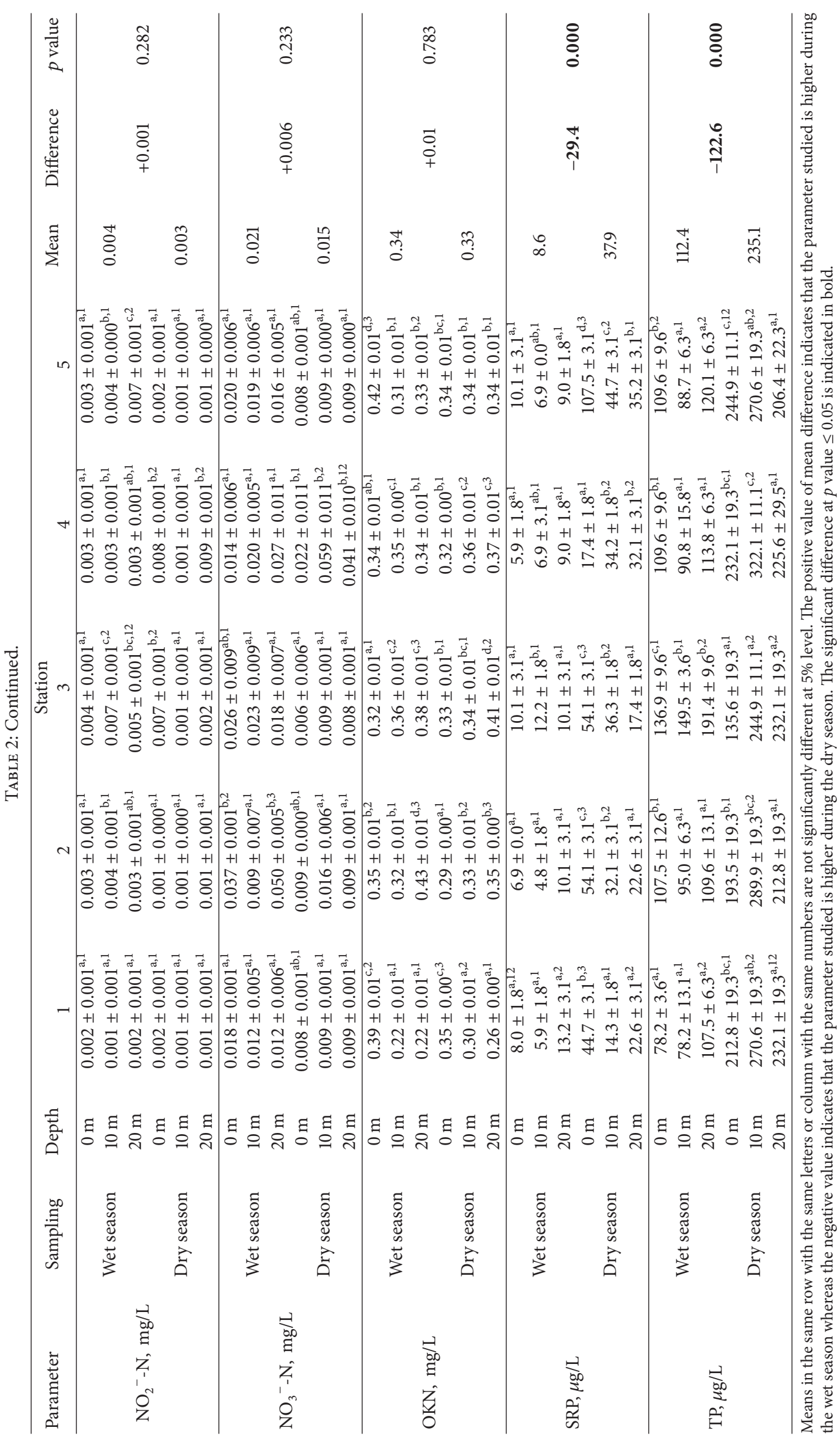



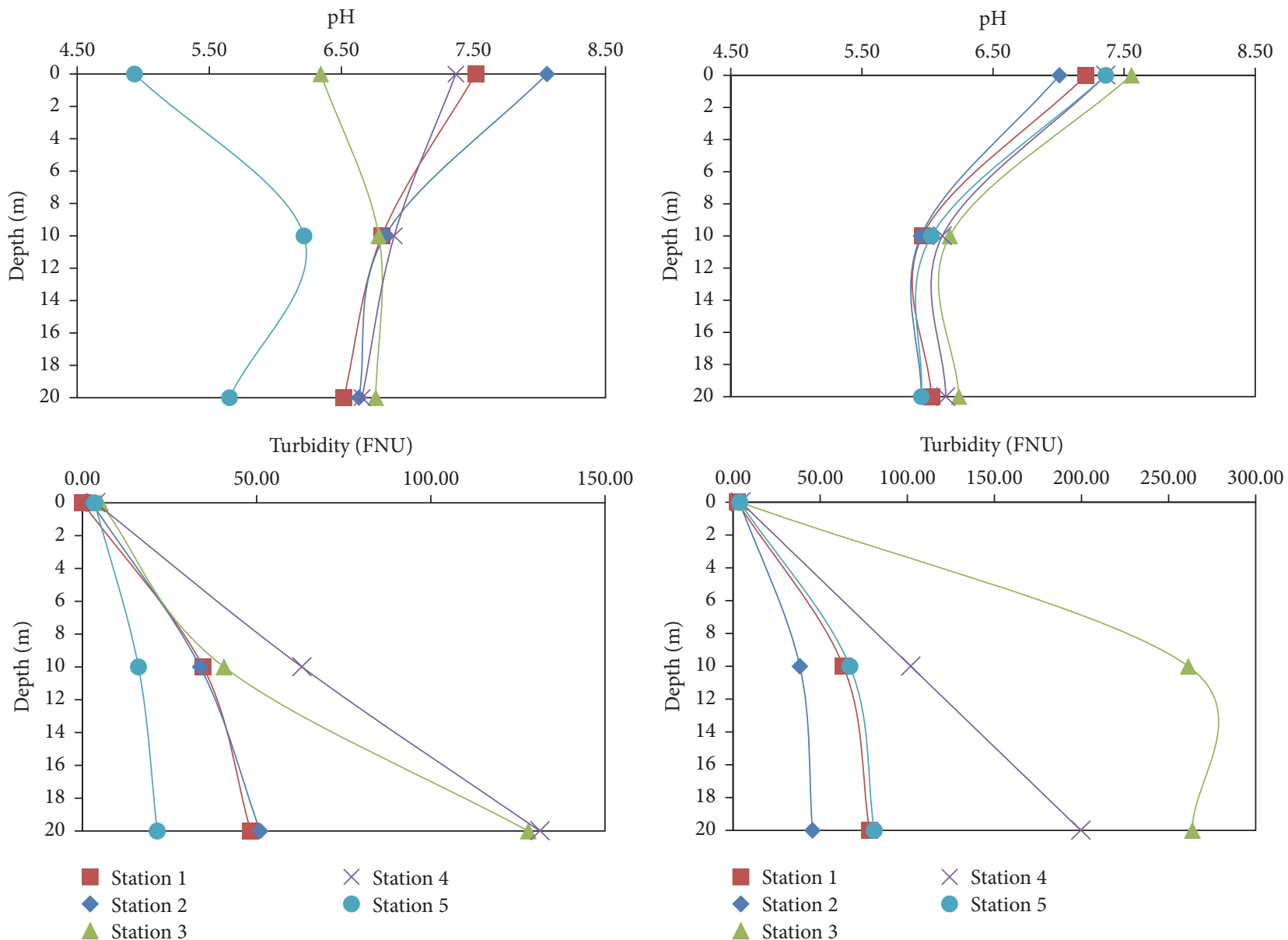

(a)

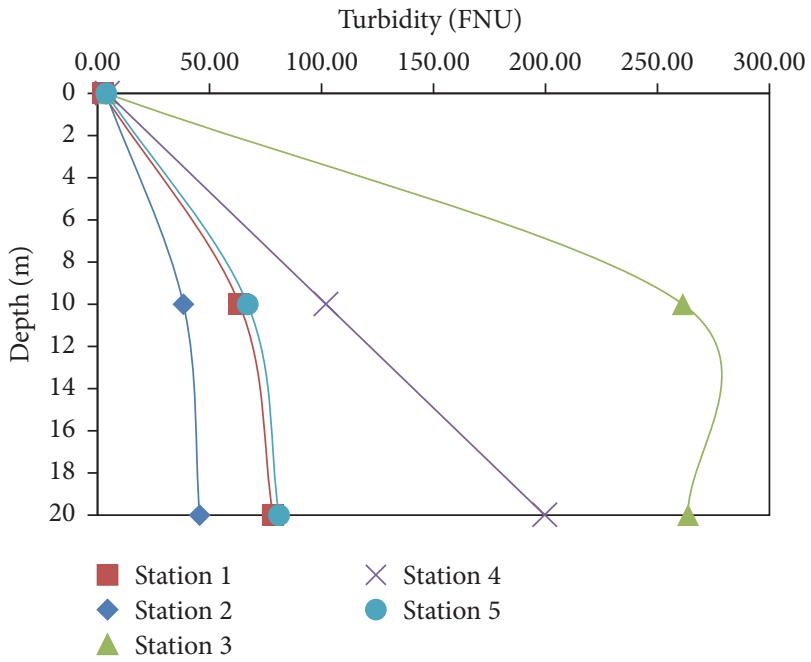

(b)

Figure 3: The distribution of $\mathrm{pH}$ and turbidity at three different depths $(0,10$, and $20 \mathrm{~m})$ of Bakun Reservoir in February (a) and September (b) 2014 .

TABLE 3: Correlation of water quality parameters of the Bakun Reservoir during the wet season $(N=15)$.

\begin{tabular}{|c|c|c|c|c|c|c|c|c|c|c|}
\hline Parameter & $\mathrm{pH}$ & Turbidity & Chl $a$ & TSS & $\mathrm{BOD}_{5}$ & $\mathrm{NO}_{2}{ }^{-}-\mathrm{N}$ & $\mathrm{NO}_{3}{ }^{-}-\mathrm{N}$ & OKN & SRP & $\mathrm{TP}$ \\
\hline $\mathrm{pH}$ & 1.000 & & & & & & & & & \\
\hline Turbidity & 0.005 & 1.000 & & & & & & & & \\
\hline Chl $a$ & 0.314 & -0.254 & 1.000 & & & & & & & \\
\hline TSS & -0.162 & $0.755^{*}$ & -0.368 & 1.000 & & & & & & \\
\hline $\mathrm{BOD}_{5}$ & -0.345 & 0.242 & -0.263 & 0.310 & 1.000 & & & & & \\
\hline $\mathrm{NO}_{2}{ }^{-}-\mathrm{N}$ & -0.288 & 0.093 & -0.383 & 0.247 & $0.674^{*}$ & 1.000 & & & & \\
\hline $\mathrm{NO}_{3}{ }^{-}-\mathrm{N}$ & 0.161 & 0.067 & 0.389 & -0.011 & 0.272 & -0.002 & 1.000 & & & \\
\hline OKN & -0.081 & 0.023 & 0.091 & -0.208 & 0.499 & 0.265 & $0.552^{*}$ & 1.000 & & \\
\hline SRP & -0.365 & 0.237 & -0.130 & 0.281 & 0.044 & 0.288 & 0.223 & 0.093 & 1.000 & \\
\hline $\mathrm{TP}$ & -0.128 & 0.474 & -0.144 & 0.217 & 0.400 & $0.620^{*}$ & 0.121 & 0.271 & $0.539^{*}$ & 1.000 \\
\hline
\end{tabular}

${ }^{*}$ The significant correlation at $p$ value $\leq 0.05$ is indicated in bold.

On the other hand, during the dry season, the $\mathrm{pH}$ value of the Bakun Reservoir was significantly positively correlated with Chl $a$ and SRP but negatively correlated with turbidity and TP ( $p$ value $\leq 0.05$ ) as shown in Table 4 . The relationship revealed that the $\mathrm{pH}$ value of the Bakun Reservoir was regulated by the process of photosynthesis and decomposition of organic matter in the reservoir during the dry season. Photosynthesis increases $\mathrm{pH}$ value in the surface water but the rate decreases with depth due to light limitation in the water column [33, 34].

The surface turbidity value of the Bakun Reservoir was low $(<6$ FNU) and increased significantly $(p$ value $\leq 0.05)$ 
TABLE 4: Correlation of water quality parameters of the Bakun Reservoir during the dry season $(N=15)$.

\begin{tabular}{|c|c|c|c|c|c|c|c|c|c|c|}
\hline Parameter & $\mathrm{pH}$ & Turbidity & Chl $a$ & TSS & $\mathrm{BOD}_{5}$ & $\mathrm{NO}_{2}^{-}-\mathrm{N}$ & $\mathrm{NO}_{3}{ }^{-}-\mathrm{N}$ & $\mathrm{OKN}$ & SRP & TP \\
\hline $\mathrm{pH}$ & 1.000 & & & & & & & & & \\
\hline Turbidity & $-0.516^{*}$ & 1.000 & & & & & & & & \\
\hline Chl $a$ & $0.676^{*}$ & -0.385 & 1.000 & & & & & & & \\
\hline TSS & -0.407 & $0.923^{*}$ & -0.259 & 1.000 & & & & & & \\
\hline $\mathrm{BOD}_{5}$ & -0.378 & 0.217 & 0.090 & 0.346 & 1.000 & & & & & \\
\hline $\mathrm{NO}_{2}{ }^{-}-\mathrm{N}$ & 0.465 & -0.008 & 0.041 & -0.048 & -0.479 & 1.000 & & & & \\
\hline $\mathrm{NO}_{3}{ }^{-}-\mathrm{N}$ & -0.192 & 0.197 & -0.293 & 0.085 & -0.405 & 0.289 & 1.000 & & & \\
\hline $\mathrm{OKN}$ & -0.085 & $0.524^{*}$ & 0.001 & $0.622^{*}$ & 0.283 & 0.166 & 0.276 & 1.000 & & \\
\hline SRP & $0.556^{*}$ & -0.361 & $0.884^{*}$ & -0.359 & -0.024 & -0.041 & -0.163 & -0.009 & 1.000 & \\
\hline $\mathrm{TP}$ & $-0.539^{*}$ & 0.205 & -0.255 & 0.128 & 0.176 & -0.406 & 0.513 & 0.103 & -0.168 & 1.000 \\
\hline
\end{tabular}

* The significant correlation at $p$ value $\leq 0.05$ is indicated in bold.

as depth increased at all stations which agrees with the previous study on the reservoir $[10,11]$. The turbidity value increased up to $131.33 \mathrm{FNU}$ and $263.67 \mathrm{FNU}$ at a depth of $20 \mathrm{~m}$ during the wet season and dry season, respectively. The surface turbidity value in the Bakun Reservoir was classified as Class I during both trips except for Station 3 during the wet season which was classified as Class II. The turbidity value exceeded the NWQS as depth increased where the turbidity value was more than 50 FNU. The turbidity value was significantly higher $(p$ value $\leq 0.05)$ at Stations 3 and 4 which are located at Murum River. Figure 3 illustrates that the turbidity value at Station 4 increased linearly during both trips while the turbidity value at Station 3 increased linearly during the wet season. The turbidity value at Station 3 increased up to $261.3 \mathrm{FNU}$ at a depth of $10 \mathrm{~m}$ and became stagnant up to a depth of $20 \mathrm{~m}$ during the dry season. The significant positive correlation between turbidity and TSS ( $p$ value $\leq 0.05)$ suggested that the turbidity resulted from the suspended solids in the water column. The land clearing coupled with the construction at the upstream area of the Murum River accelerated the soil erosion and sedimentation and the resulting suspended solids were transported into the reservoir during surface runoff and were deposited at the bottom of the reservoir. The high turbidity value which increased with depth was most likely due to the settling and resuspension of settled solids. The turbidity value at Station 3 was recorded up to $1000 \mathrm{FNU}$ at a depth of $15 \mathrm{~m}$ and $30 \mathrm{~m}$ in the year 2013 [13]. The present study did demonstrate an improvement in the water turbidity over time although the value still exceeded the standard. Turbidity was also significantly positively correlated with OKN ( $p$ value $\leq 0.05$ ) during the dry season. Many pollutants are attaching to the particles; thus, an increase in particles in the reservoir results in an increase in OKN in the present study.

The surface Chl a concentration ranged from $0.62 \pm$ $0.21 \mu \mathrm{g} / \mathrm{L}$ to $2.30 \pm 0.81 \mu \mathrm{g} / \mathrm{L}$ and from $0.64 \pm 0.02 \mu \mathrm{g} / \mathrm{L}$ to $5.87 \pm 0.99 \mu \mathrm{g} / \mathrm{L}$ in the Bakun Reservoir during the wet and dry seasons, respectively. The vertical distribution of Chl $a$ in the Bakun Reservoir shows that Chl $a$ decreased with depth or remained at similar concentrations in the water column (Figure 4). Sufficient light availability on the surface water promoted the growth of phytoplankton leading to the highest concentration of Chl $a$ in the surface water whereas light limitation as depth increased reduced the growth of the phytoplankton in the present study. However, in studies such as [27], the Chl $a$ concentration exhibited a different trend where the Chl a concentration was the highest at a depth of $10 \mathrm{~m}$ compared to the surface water. The authors attributed this observation to the unfavorable high temperature and irradiance in the surface water for the phytoplankton. Nevertheless, the authors reported that the Chl $a$ concentration was the lowest at a depth of $30 \mathrm{~m}$ due to the light limitation in the reservoir.

Previously, the highest concentration of $7.25 \mu \mathrm{g} / \mathrm{L}$ of $\mathrm{Chl}$ $a$ was reported in the surface water of Bakun Reservoir [11] whereas the Chl a concentration was reported up to $4.58 \mathrm{mg} / \mathrm{m}^{3}$ [35] and $6.02 \mathrm{mg} / \mathrm{m}^{3}$ [28] in the surface water of the Batang Ai Reservoir. The high Chl $a$ in the Batang $\mathrm{Ai}$ Reservoir was attributed to the cage culture activities in the reservoir [35] whereas the high Chl a concentration in the present study was most likely due to the nutrient availability from the anthropogenic activities in the adjacent area. In the present study, Chl $a$ was significantly positively correlated with SRP during the dry season ( $p$ value $\leq 0.05$ ). The positive correlation between $\mathrm{Chl} a$ and SRP reveals that the growth of phytoplankton in the Bakun Reservoir was not limited by the phosphorus.

All surface TSS values in Bakun Reservoir were classified as Class I which is less than $25 \mathrm{mg} / \mathrm{L}$. The surface TSS concentration in the present study was lower than the previously reported surface TSS concentration $(66.7-100.0 \mathrm{mg} / \mathrm{L})$ in the year 2013 [11]. The improvement of TSS concentration demonstrated the settling of the suspended solids in the reservoir over time. The old Batang Ai Reservoir also contained low TSS values which are less than $25 \mathrm{mg} / \mathrm{L}$ even at a depth of $30 \mathrm{~m}$ [35]. The vertical distribution of TSS exhibited a similar trend with turbidity where the TSS value increased significantly ( $p$ value $\leq 0.05$ ) as depth increased in the present study. Figure 4 shows that Station 3 contained the highest TSS concentration as depth increased during the dry season, followed by Station 4 where both stations were located at the Murum River. The extremely high TSS concentrations at 

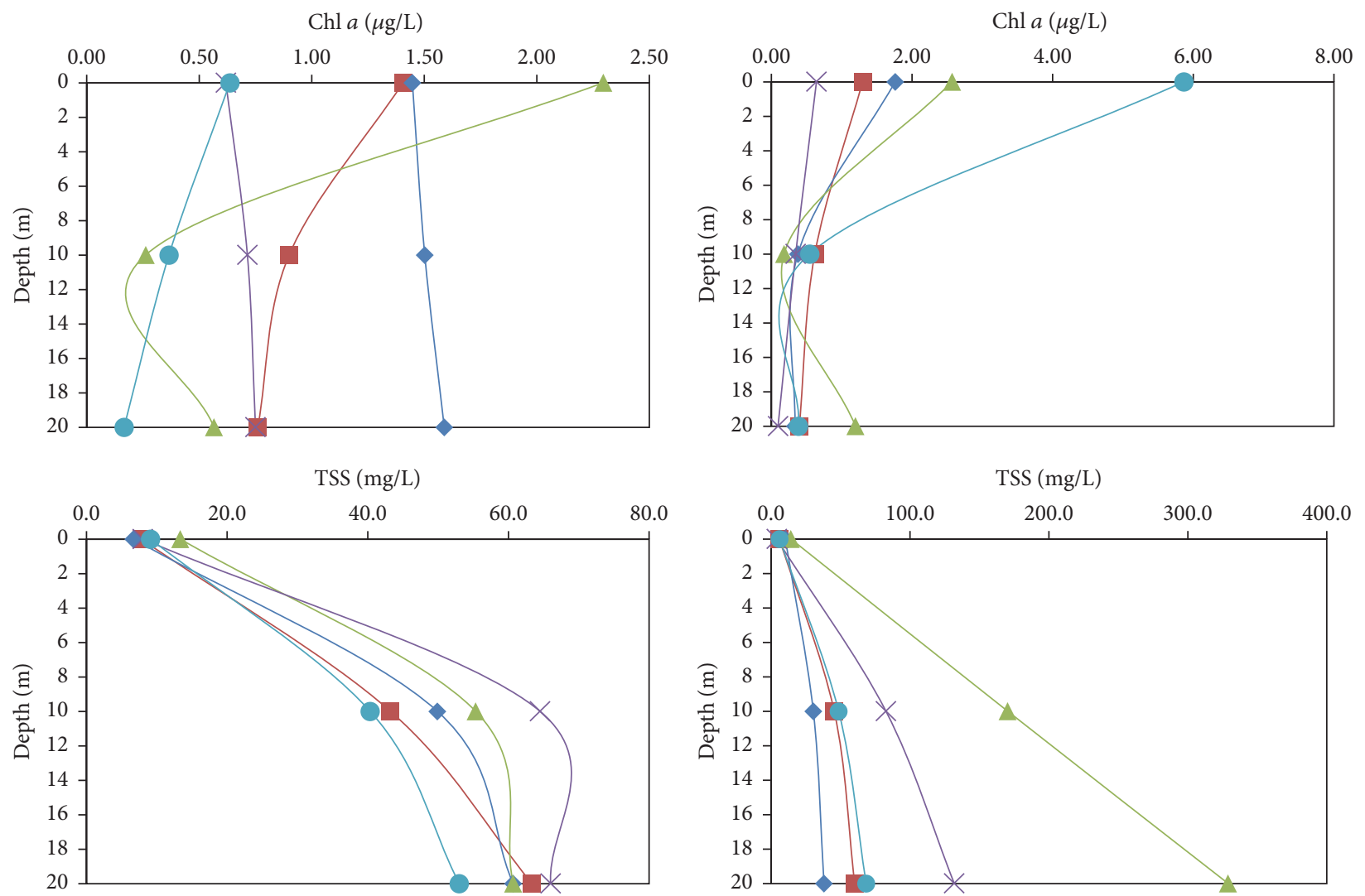

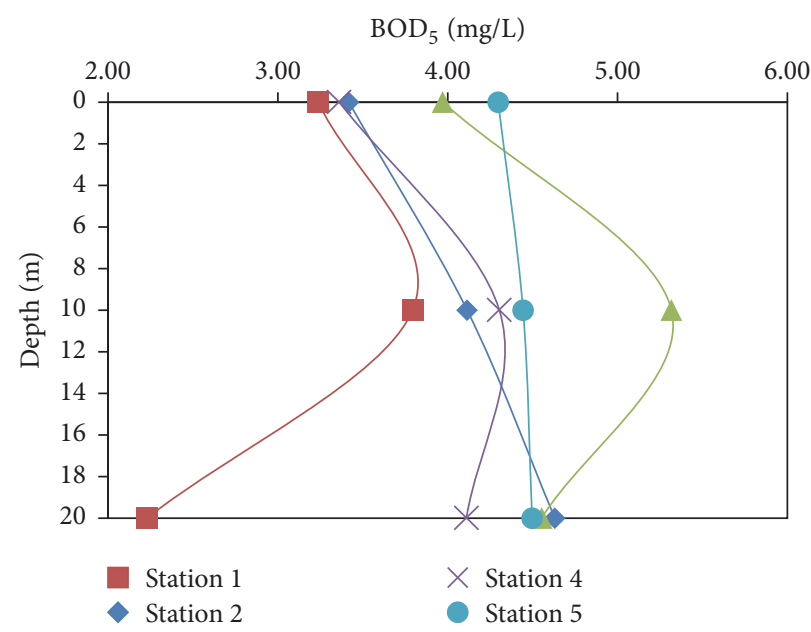

(a)

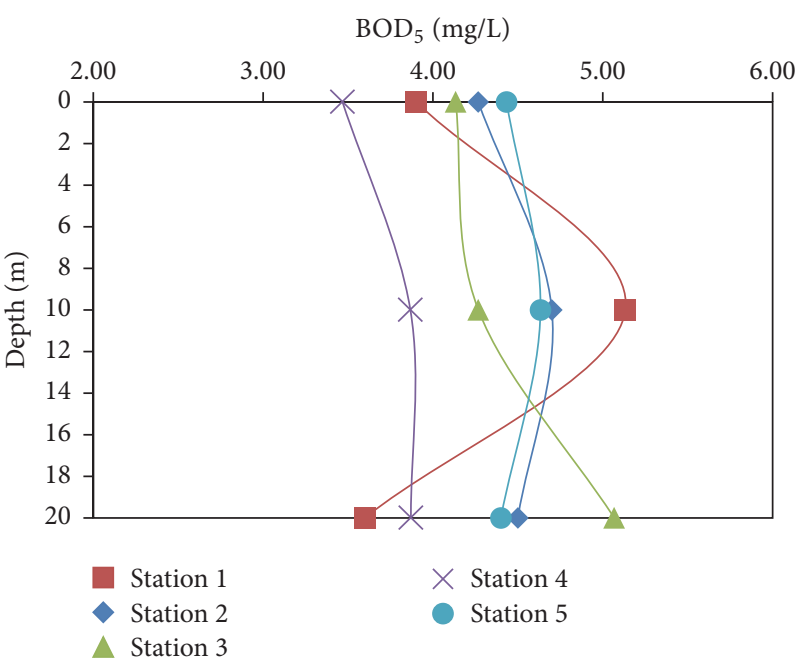

(b)

Figure 4: The distribution of Chl $a$, TSS, and $\mathrm{BOD}_{5}$ at three different depths $(0,10$, and $20 \mathrm{~m}$ ) of Bakun Reservoir in February (a) and September (b) 2014.

Stations 3 and 4 revealed the impact of the land clearing and dam construction upstream of the river that carries eroded soil particles into the reservoir.

Surface $\mathrm{BOD}_{5}$ concentration at the Bakun Reservoir ranged from $3.24 \pm 0.19 \mathrm{mg} / \mathrm{L}$ to $4.30 \pm 0.15 \mathrm{mg} / \mathrm{L}$ and from $3.47 \pm 0.06 \mathrm{mg} / \mathrm{L}$ to $4.43 \pm 0.06 \mathrm{mg} / \mathrm{L}$ during the wet and dry seasons, respectively. Table 2 shows that Stations 3 and 5 often contained significantly higher $\mathrm{BOD}_{5}$ concentrations
( $p$ value $\leq 0.05)$ at the three different depths of the water column. The high $\mathrm{BOD}_{5}$ concentrations at the two stations downstream of the construction of the Murum hydroelectric dam and logging activities show organic matter loading from the anthropogenic activities into the reservoir. $\mathrm{BOD}_{5}$ concentrations decreased to a value of $2.23 \mathrm{mg} / \mathrm{L}$ at a depth of $20 \mathrm{~m}$ at Station 1, classified as Class II. Other than that, $\mathrm{BOD}_{5}$ concentrations in the Bakun Reservoir were classified 
as Class III. In contrast to the TSS concentration, the surface $\mathrm{BOD}_{5}$ concentration in the present study was higher than the surface $\mathrm{BOD}_{5}$ concentration $(<2 \mathrm{mg} / \mathrm{L})$ in the year 2013 [13]. The elevated $\mathrm{BOD}_{5}$ concentration in the reservoir indicates high loading and accumulation of organic matter in the Bakun Reservoir over time. However, the present surface $\mathrm{BOD}_{5}$ concentration was lower than the $\mathrm{BOD}_{5}$ concentration in the Batang Ai Reservoir where up to $12 \mathrm{mg} / \mathrm{L}$ of $\mathrm{BOD}_{5}$ concentration was reported [35].

The $\mathrm{NO}_{2}{ }^{-}-\mathrm{N}$ concentration was low in the Bakun Reservoir. The surface $\mathrm{NO}_{2}{ }^{-}-\mathrm{N}$ concentrations were not significantly different ( $p$ value $>0.05$ ) among the stations during the wet season with a mean of $0.003 \mathrm{mg} / \mathrm{L}$. During the dry season, the highest value of surface $\mathrm{NO}_{2}{ }^{-} \mathrm{-N}$ was observed at Station $4(0.008 \pm 0.001 \mathrm{mg} / \mathrm{L})$ followed by Station 3 $(0.007 \pm 0.001 \mathrm{mg} / \mathrm{L})$ which were significantly higher $(p$ value $\leq 0.05)$ than other stations $(\approx 0.002 \mathrm{mg} / \mathrm{L})$. Similarly, the surface $\mathrm{NO}_{3}{ }^{-}-\mathrm{N}$ concentration was generally low in the Bakun Reservoir, ranging from $0.014 \pm 0.006 \mathrm{mg} / \mathrm{L}$ to $0.037 \pm$ $0.001 \mathrm{mg} / \mathrm{L}$ during the wet season. The mean concentration of surface $\mathrm{NO}_{3}{ }^{-}-\mathrm{N}$ in the Bakun Reservoir during the dry season was $0.008 \mathrm{mg} / \mathrm{L}$ except at Station 4 which exhibited a peak of $0.022 \pm 0.011 \mathrm{mg} / \mathrm{L}$. The highest concentrations of $\mathrm{NO}_{3}{ }^{-} \mathrm{N}$ in the reservoir were observed at Station 2 at a depth of $20 \mathrm{~m}(0.050 \mathrm{mg} / \mathrm{L})$ and Station $4(0.059 \mathrm{mg} / \mathrm{L})$ during the wet and dry seasons, respectively. Comparisons of the results with NWQS indicated that $\mathrm{NO}_{2}{ }^{-}{ }^{-} \mathrm{N}$ and $\mathrm{NO}_{3}{ }^{-}$$\mathrm{N}$ in the Bakun Reservoir were classified as Class I. Surface OKN concentrations of the Bakun Reservoir ranged from $0.32 \pm 0.01 \mathrm{mg} / \mathrm{L}$ to $0.42 \pm 0.01 \mathrm{mg} / \mathrm{L}$ and from $0.29 \pm$ $0.01 \mathrm{mg} / \mathrm{L}$ to $0.35 \pm 0.01 \mathrm{mg} / \mathrm{L}$ during the wet and dry seasons, respectively. Significantly high concentrations of OKN ( $p$ value $\leq 0.05)$ were observed at Stations 4 and 5 during the wet and dry seasons which are predominantly from the surface runoff from the anthropogenic activities as mentioned above. Similar to the $\mathrm{BOD}_{5}$ concentration, no obvious trend was observed in the vertical distribution of OKN concentrations in the Bakun Reservoir (Figure 5).

The $\mathrm{NO}_{2}{ }^{-}-\mathrm{N}$ concentration in the present study is within the range of $\mathrm{NO}_{2}{ }^{-}-\mathrm{N}(0.0003-0.0083 \mathrm{mg} / \mathrm{L})$ reported in the year 2013 [11] and lower than the $\mathrm{NO}_{2}{ }^{-}-\mathrm{N}$ concentration (0.001-0.053 mg/L) in the Batang Ai Reservoir [35]. On the other hand, the $\mathrm{NO}_{3}{ }^{-}-\mathrm{N}$ concentration in the present study is within the range of $\mathrm{NO}_{3}{ }^{-}-\mathrm{N}(0.01-0.06 \mathrm{mg} / \mathrm{L})$ in the Batang Ai Reservoir [35] but the $\mathrm{NO}_{3}{ }^{-}-\mathrm{N}$ concentrations in Station 2 during the wet season and Station 4 during the dry season were higher than the range of $\mathrm{NO}_{3}{ }^{-}-\mathrm{N}(0.003-0.027 \mathrm{mg} / \mathrm{L})$ reported in the Bakun Reservoir in the year 2013 [11]. $\mathrm{NO}_{2}{ }^{-}-\mathrm{N}$ was significantly positively correlated with TP and $\mathrm{BOD}_{5}$ ( $p$ value $\leq 0.05$ ), and $\mathrm{OKN}$ was significantly positively correlated with $\mathrm{NO}_{3}{ }^{-}-\mathrm{N}(p$ value $\leq 0.05)$ during the wet season. The relationship indicated the active decomposition and nitrification process in the reservoir. The relatively higher $\mathrm{NO}_{3}{ }^{-}-\mathrm{N}$ concentration in the reservoir compared to the year 2013 indicated that nitrogen in the reservoir is being converted to $\mathrm{NO}_{3}{ }^{-}-\mathrm{N}$ which is less toxic to aquatic organisms in the reservoir.

The concentration of SRP was low and relatively consistent in the Bakun Reservoir during the wet season with a mean value of $8.6 \mu \mathrm{g} / \mathrm{L}$. The highest concentration of SRP $(13.2 \mu \mathrm{g} / \mathrm{L})$ was observed at Station 1 at a depth of $20 \mathrm{~m}$. The SRP concentration was significantly higher during the dry season in the Bakun Reservoir ( $p$ value $\leq 0.05$ ) with a mean value of $37.9 \mu \mathrm{g} / \mathrm{L}$. The lowest and the highest concentrations of surface SRP were observed at Station $4(17.4 \pm 1.8 \mu \mathrm{g} / \mathrm{L})$ and Station $5(107.5 \pm 3.1 \mu \mathrm{g} / \mathrm{L})$, respectively, and significantly differed ( $p$ value $\leq 0.05$ ) from other stations in the reservoir. Figure 6 illustrates that most stations in the Bakun Reservoir exhibited similar vertical distributions of SRP concentration during the dry season except for Station 4 . The SRP concentration significantly decreased $(p$ value $\leq 0.05)$ as depth increased in the Bakun Reservoir except at Station 4 where the surface SRP concentration was significantly lower ( $p$ value $\leq 0.05$ ) than the SRP concentration at depths of $10 \mathrm{~m}$ and $20 \mathrm{~m}$. Reference [26] reported that phosphate was lower in hypolimnion $(>2.5 \mu \mathrm{M})$ compared to the surface water $(0.05-0.23 \mu \mathrm{M})$ in the Cirata Reservoir which could be caused by enhanced loading from the sediment in the anoxic condition. The SRP concentration in the present study was lower than the SRP concentration in the year 2013 where the highest SRP concentration was $652.2 \mu \mathrm{g} / \mathrm{L}$ [11].

Surface TP of the Bakun Reservoir ranged from $78.2 \pm$ $3.6 \mu \mathrm{g} / \mathrm{L}$ to $136.9 \pm 9.6 \mu \mathrm{g} / \mathrm{L}$ and from $135.6 \pm 19.3 \mu \mathrm{g} / \mathrm{L}$ to $244.9 \pm 11.1 \mu \mathrm{g} / \mathrm{L}$ during the wet and dry seasons, respectively. Similar to the SRP, TP concentration was significantly higher during the dry season ( $p$ value $\leq 0.05$ ) in the Bakun Reservoir. This shows that high precipitation during the wet season and the elevated reservoir water volume diluted both SRP and TP substantially in the reservoir. A similar observation where TP showed lower concentrations during the rainy season and high water level $(24.90-38.59 \mu \mathrm{g} / \mathrm{L})$ than the dry season and low water level $(45.94-67.28 \mu \mathrm{g} / \mathrm{L})$ was reported in the Batang Ai Reservoir [20]. The present TP concentration in the Bakun Reservoir was higher than the TP concentration in the Batang Ai Reservoir during both seasons. Figure 6 illustrates that the vertical distribution of TP concentration is relatively consistent in the Bakun Reservoir but shows an opposite trend between the wet and dry seasons. The TP concentration was the lowest at the depth of $10 \mathrm{~m}$ during the wet season but became the highest during the dry season. Station 3 contained significantly higher TP concentrations at $0 \mathrm{~m}, 10 \mathrm{~m}$, and $20 \mathrm{~m}$ ( $p$ value $\leq 0.05)$ in the reservoir during the wet season, suggesting that the phosphorus originates from the surface runoff from the Murum Dam construction. The intensity of the impact increased substantially during the wet season as more phosphorus is washed down into the reservoir. In the present study, SRP concentrations complied with the $200 \mu \mathrm{g} / \mathrm{L}$ standard in accordance with the NWQS [32] during both trips. The TP concentration complied with the NWQS during the wet season but was noncompliant with the standard when the TP concentration increased substantially during the dry season.

3.2. Water Quality of the Downstream River of the Bakun Hydroelectric Dam. Table 5 summarizes the in situ and ex situ water quality of the downstream river of the Bakun Dam during the wet and dry seasons. The result demonstrated that 

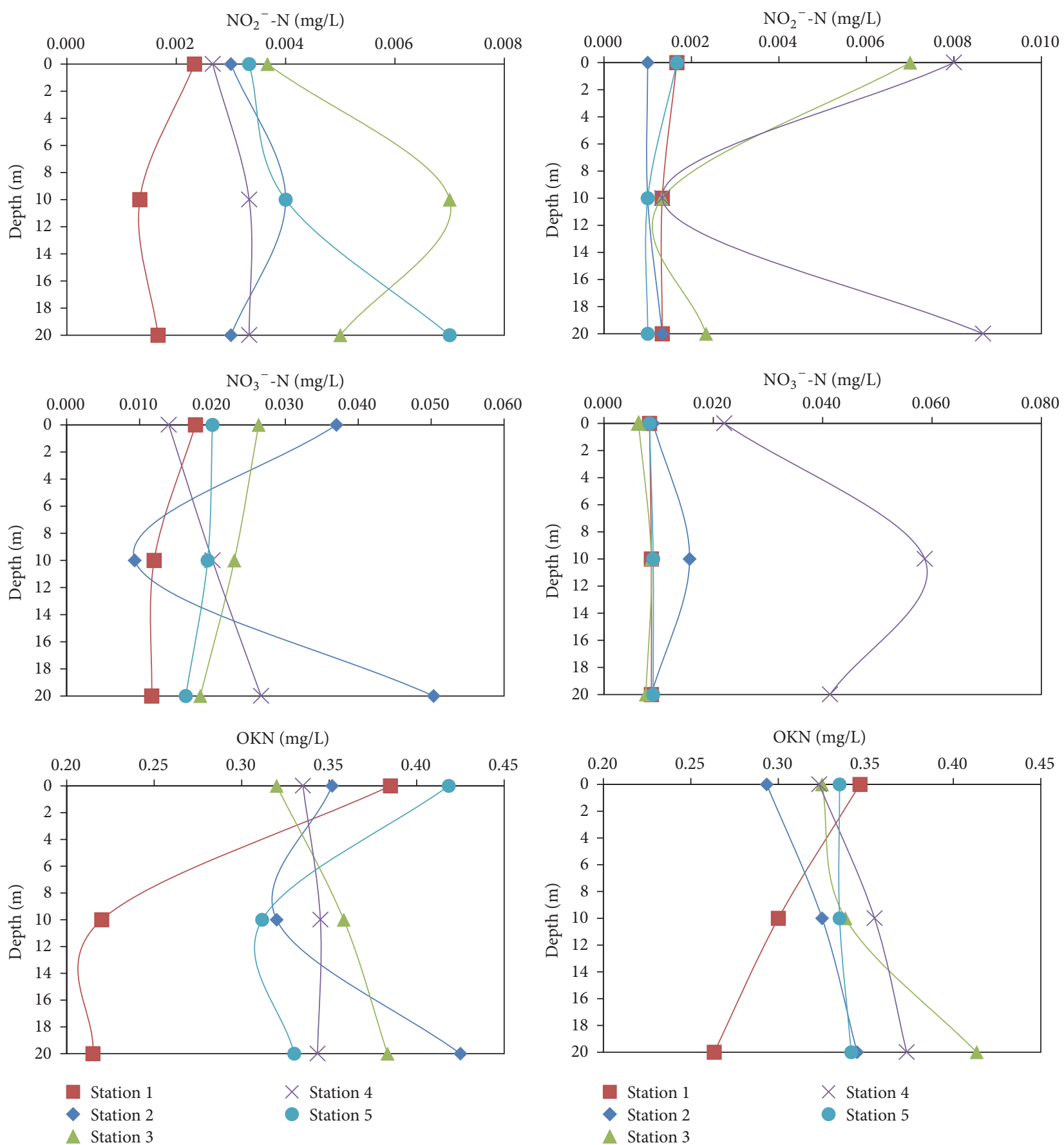

(a)

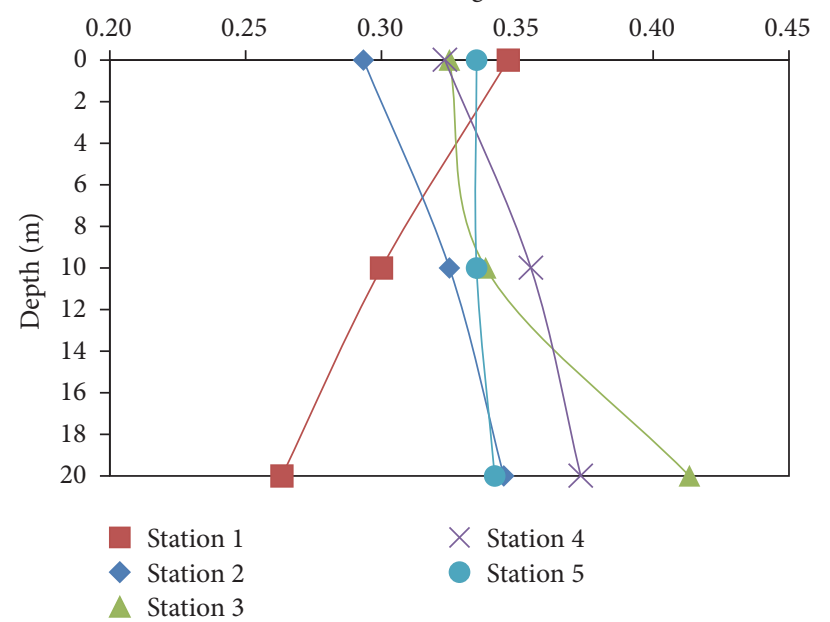

(b)

FIGURE 5: The distribution of $\mathrm{NO}_{2}{ }^{-}-\mathrm{N}, \mathrm{NO}_{3}{ }^{-}-\mathrm{N}$, and $\mathrm{OKN}$ at three different depths $(0,10$, and $20 \mathrm{~m})$ of Bakun Reservoir in February (a) and September (b) 2014.

the reservoir water has altered the surface water temperature of the downstream river. When the cooler reservoir water at a depth of $10 \mathrm{~m}$ is released into the downstream river, it decreased approximately $4^{\circ} \mathrm{C}$ to $5^{\circ} \mathrm{C}$ of the surface water temperature of its downstream river. The mean value of DO in the downstream river was $9.40 \mathrm{mg} / \mathrm{L}$ and $2.59 \mathrm{mg} / \mathrm{L}$ during the wet and dry seasons and was classified as Class I and Class IV, respectively. Both DO values in the downstream river were higher than the DO value of the reservoir water at a depth of $10 \mathrm{~m}(<1 \mathrm{mg} / \mathrm{L})$, particularly the DO content during the wet season because the spillway of the dam was open and additional water was discharged from the spillway during the sampling. The strong water current from the spillway coupled with the water flow from the turbines promotes aeration and increases the DO content substantially. On the other hand, the DO content was low when the spillway was 

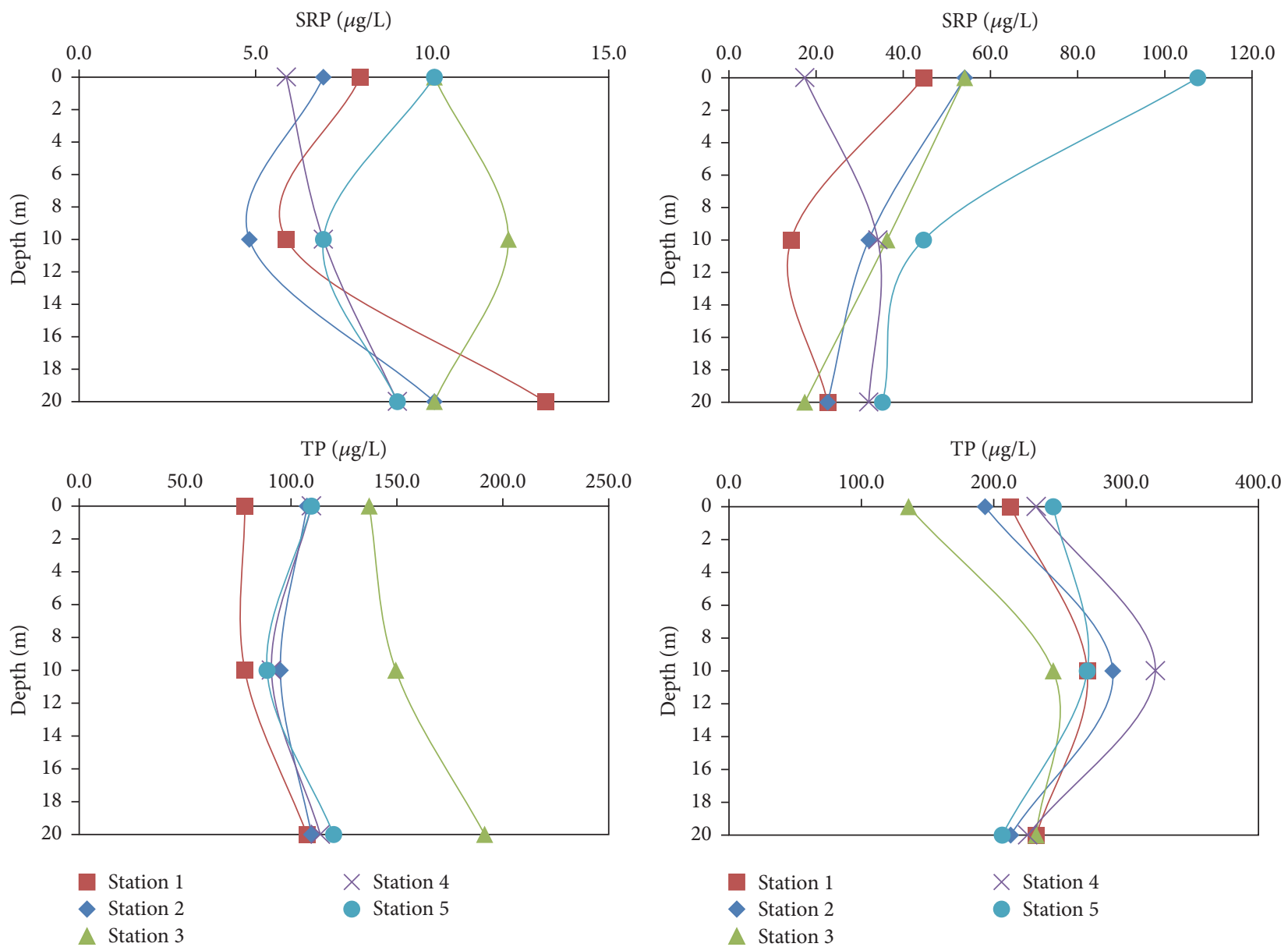

(a)

(b)

FIGURE 6: The distribution of SRP and TP at three different depths $(0,10$, and $20 \mathrm{~m})$ of Bakun Reservoir in February (a) and September (b) 2014.

TABLE 5: Summary of the mean and standard deviation of the in situ and ex situ water quality parameters in the downstream river of the Bakun Dam (Station 6) and the mean difference of the parameters between the wet and dry seasons $(N=3)$.

\begin{tabular}{|c|c|c|c|c|}
\hline Parameter & Wet season & Dry season & Mean difference & $p$ value \\
\hline \multicolumn{5}{|l|}{ In situ } \\
\hline Temperature, ${ }^{\circ} \mathrm{C}$ & $25.0 \pm 0.0$ & $27.1 \pm 0.1$ & -2.1 & 0.000 \\
\hline $\mathrm{DO}, \mathrm{mg} / \mathrm{L}$ & $9.40 \pm 0.10$ & $2.59 \pm 0.05$ & +6.81 & 0.000 \\
\hline $\mathrm{pH}$ & $6.2 \pm 0.01$ & $6.0 \pm 0.01$ & +0.2 & 0.001 \\
\hline Turbidity, FNU & $77.00 \pm 1.00$ & $113.67 \pm 0.58$ & -36.67 & 0.000 \\
\hline \multicolumn{5}{|l|}{ Ex situ } \\
\hline $\mathrm{Chl} a, \mu \mathrm{g} / \mathrm{L}$ & $0.64 \pm 0.06$ & $0.52 \pm 0.06$ & +0.12 & 0.179 \\
\hline TSS, mg/L & $45.0 \pm 1.7$ & $61.7 \pm 1.4$ & -16.7 & 0.011 \\
\hline $\mathrm{BOD}_{5}, \mathrm{mg} / \mathrm{L}$ & $5.70 \pm 0.03$ & $3.10 \pm 0.10$ & +2.60 & 0.000 \\
\hline $\mathrm{NO}_{2}{ }^{-}-\mathrm{N}, \mathrm{mg} / \mathrm{L}$ & $0.007 \pm 0.001$ & $0.001 \pm 0.001$ & +0.006 & 0.009 \\
\hline $\mathrm{NO}_{3}{ }^{-}-\mathrm{N}, \mathrm{mg} / \mathrm{L}$ & $0.023 \pm 0.010$ & $0.009 \pm 0.001$ & +0.014 & 0.115 \\
\hline $\mathrm{OKN}, \mathrm{mg} / \mathrm{L}$ & $0.40 \pm 0.01$ & $0.38 \pm 0.00$ & +0.01 & 0.057 \\
\hline $\mathrm{SRP}, \mu \mathrm{g} / \mathrm{L}$ & $10.1 \pm 3.1$ & $34.2 \pm 1.8$ & -24.1 & 0.008 \\
\hline $\mathrm{TP}, \mu \mathrm{g} / \mathrm{L}$ & $99.2 \pm 9.6$ & $386.4 \pm 19.3$ & -287.2 & 0.001 \\
\hline
\end{tabular}

The positive value of mean difference indicates that the parameter studied is higher during the wet season whereas the negative value indicates that the parameter studied is higher during the dry season. 
TABLE 6: Mean difference of in situ and ex situ water quality parameters between the intake point of the dam at $10 \mathrm{~m}$ (Station 5) and its downstream river (Station 6) during wet and dry seasons $(N=3)$.

\begin{tabular}{|c|c|c|c|c|}
\hline \multirow{2}{*}{ Parameter } & \multicolumn{2}{|c|}{ Wet season } & \multicolumn{2}{|c|}{ Dry season } \\
\hline & Mean difference & $p$ value & Mean difference & $p$ value \\
\hline \multicolumn{5}{|l|}{ In situ } \\
\hline $\mathrm{pH}$ & -0.03 & 0.469 & +0.01 & 0.288 \\
\hline Turbidity, FNU & +60.9 & 0.000 & +46.7 & 0.000 \\
\hline \multicolumn{5}{|l|}{ Ex situ } \\
\hline $\mathrm{Chl} a, \mu \mathrm{g} / \mathrm{L}$ & +0.28 & 0.013 & -0.02 & 0.755 \\
\hline TSS, mg/L & +4.67 & 0.011 & +13.03 & 0.000 \\
\hline $\mathrm{BOD}_{5}, \mathrm{mg} / \mathrm{L}$ & +1.26 & 0.000 & -1.53 & 0.000 \\
\hline $\mathrm{NO}_{2}{ }^{-}-\mathrm{N}, \mathrm{mg} / \mathrm{L}$ & +0.003 & 0.001 & +0.000 & 0.374 \\
\hline $\mathrm{NO}_{3}{ }^{-}-\mathrm{N}, \mathrm{mg} / \mathrm{L}$ & +0.003 & 0.631 & -0.000 & 0.374 \\
\hline $\mathrm{OKN}, \mathrm{mg} / \mathrm{L}$ & +0.08 & 0.000 & +0.05 & 0.000 \\
\hline $\mathrm{SRP}, \mu \mathrm{g} / \mathrm{L}$ & +3.2 & 0.157 & -10.5 & 0.007 \\
\hline $\mathrm{TP}, \mu \mathrm{g} / \mathrm{L}$ & +10.5 & 0.189 & +115.7 & 0.002 \\
\hline
\end{tabular}

The positive value of mean difference indicates that the parameter studied is higher in the downstream river whereas the negative value indicates that the parameter studied is lower in the downstream river.

not open during the sampling in the dry season. When the oxygen-deprived reservoir water was released into the downstream river without additional aeration, it decreased the oxygen level of the downstream river below the minimum requirement of $5 \mathrm{mg} / \mathrm{L}$ for sensitive aquatic organisms.

Low $\mathrm{pH}$ values $(\approx 6.1)$ were observed at the downstream river and classified as Class II according to NWQS [32]. Table 6 shows that there was no significant difference in $\mathrm{pH}$ value between Station 6 and the dam intake point at $10 \mathrm{~m}$ for both seasons ( $p$ value $>0.05$ ) revealing that the low $\mathrm{pH}$ in the downstream river is due to the low $\mathrm{pH}$ of the reservoir water that was released into the downstream river after passing through the turbines. The $\mathrm{pH}$ value of the downstream river was relatively lower than the $\mathrm{pH}$ value of tributaries that flow into the Bakun Reservoir (6.8-7.8) [14]. The turbidity value in the downstream river of the dam was high and exceeded the standard guideline of $50 \mathrm{FNU}$ in Malaysia [32]. The turbidity values were also significantly higher ( $p$ value $>0.05)$ than the reservoir water during both seasons. When water is discharged from the spillway in addition to turbine outflow, resuspension of deposited sediments under the high flow rate increases the suspended solids downstream. The turbidity value $(77.00 \pm 1.00 \mathrm{FNU})$ during the wet season was significantly lower ( $p$ value $>0.05$ ) than the dry season $(113.67 \pm 0.58 \mathrm{FNU})$ which is most probably due to more dilution from the tributaries along the downstream river during the wet season. Similar to the turbidity value, the TSS concentration during the wet season was significantly lower than the dry season ( $p$ value $\leq 0.05)$ and was classified as Class II and Class III, respectively. Both values were also significantly higher than the TSS concentration ( $p$ value $\leq$ $0.05)$ at the intake point.

There was no significant difference in Chl $a$ between the wet and dry seasons ( $p$ value $>0.05$ ) in the downstream river with a mean value of $0.58 \mu \mathrm{g} / \mathrm{L}$. The Chl $a$ concentration was significantly higher ( $p$ value $\leq 0.05$ ) than the intake point during the wet season but it was similar to the Chl $a$ concentration at surface reservoir water $(0.64 \mu \mathrm{g} / \mathrm{L})$. There was no significant difference in Chl $a$ between downstream river and the intake point ( $p$ value $>0.05)$ during the dry season. The mean value of $\mathrm{BOD}_{5}$ in the downstream river was $5.70 \mathrm{mg} / \mathrm{L}$ and $3.10 \mathrm{mg} / \mathrm{L}$ during the wet and dry seasons and was classified as Class III. The $\mathrm{BOD}_{5}$ concentration during the wet season was significantly higher than the dry season $(p$ value $\leq 0.05$ ). Besides, the downstream $\mathrm{BOD}_{5}$ concentration was significantly higher than the $\mathrm{BOD}_{5}$ concentration at the intake point $(p$ value $\leq 0.05)$ during the wet season whereas the $\mathrm{BOD}_{5}$ concentration was significantly lower than the $\mathrm{BOD}_{5}$ concentration at the intake point ( $p$ value $\leq 0.05$ ) during the dry season. The higher downstream $\mathrm{BOD}_{5}$ concentration during the wet season indicates that the high $\mathrm{BOD}_{5}$ concentration is most likely attributed to other domestic discharge and runoff in addition to the reservoir water. Several longhouses and villages located along the downstream river may have contributed substantial organic matter to the downstream river.

$\mathrm{NO}_{2}{ }^{-}-\mathrm{N}$ and $\mathrm{NO}_{3}{ }^{-}-\mathrm{N}$ concentrations were also low in the downstream river, similar to the reservoir water, and were classified as Class I according to NWQS [32]. Significantly higher $\mathrm{NO}_{2}{ }^{-}-\mathrm{N}$ concentration $(p$ value $\leq 0.05$ ) was found during the wet season whereas no significant difference of $\mathrm{NO}_{3}{ }^{-}-\mathrm{N}$ concentration was found between the wet and dry seasons $\left(p\right.$ value $>0.05$ ). The downstream $\mathrm{NO}_{2}{ }^{-}-\mathrm{N}$ concentration was also significantly higher than the reservoir $\mathrm{NO}_{2}{ }^{-}-\mathrm{N}$ concentration at the intake point. There was no significant difference in OKN between the wet and dry seasons ( $p$ value $>0.05$ ) in the downstream river with a mean value of $0.39 \mathrm{mg} / \mathrm{L}$. OKN was significantly higher $(p$ value $\leq 0.05)$ at the downstream river than the OKN concentration at intake point. The higher downstream $\mathrm{NO}_{2}{ }^{-}$$\mathrm{N}$ and $\mathrm{OKN}$ concentrations besides $\mathrm{BOD}_{5}$ demonstrated 


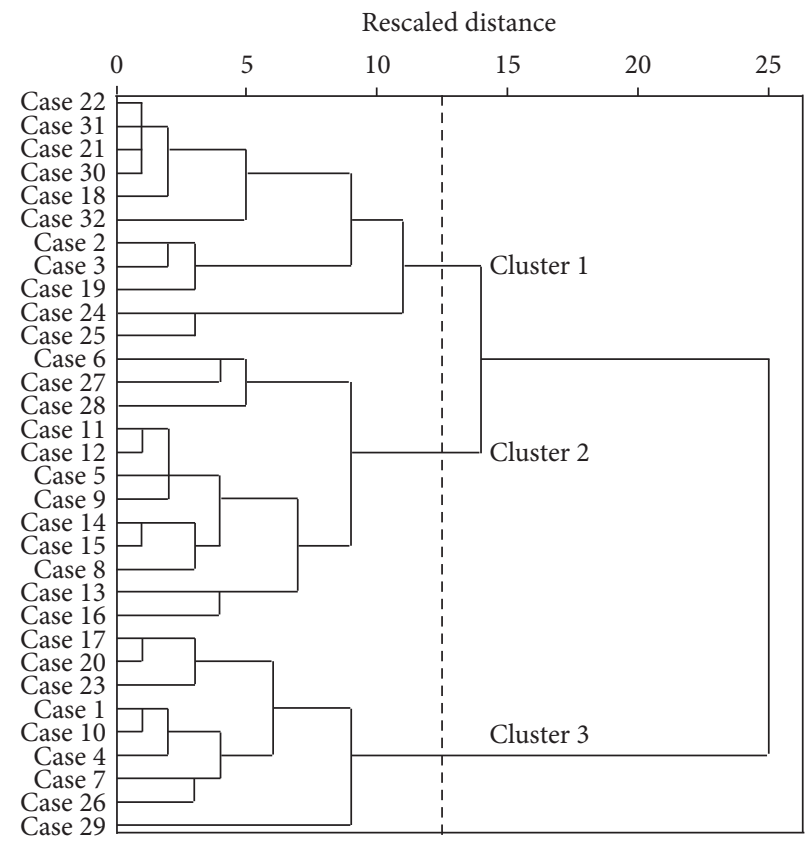

\author{
Wet season: Cases 1 to 16 \\ Dry season: Cases 17 to 32 \\ $0 \mathrm{~m}$ depth: Cases 1, 4, 7, 10, 13, 16, 17, 20, 23, 26, 29, and 32 \\ $10 \mathrm{~m}$ depth: Cases 2, 5, 8, 11, 14, 18, 21, 24, 27, and 30 \\ $20 \mathrm{~m}$ depth: Cases 3, 6, 9, 12, 15, 19, 22, 25, 28, and 31
}

Figure 7: Clusters of the five sampling stations located in Bakun Reservoir at three different depths $(0 \mathrm{~m}, 10 \mathrm{~m}$, and $20 \mathrm{~m})$ and one station located at its downstream river collected at $0 \mathrm{~m}$ during dry and wet seasons in Sarawak, Malaysia.

the organic pollutant contribution from adjacent domestic discharge and runoff in the downstream river.

SRP and TP concentrations in the downstream river exhibited a similar trend where the concentration during the wet season was significantly lower than during the dry season $(p$ value $\leq 0.05)$. The downstream SRP concentration complied with the $200 \mu \mathrm{g} / \mathrm{L}$ standard in accordance with the NWQS [32] in both trips. On the other hand, the downstream TP concentration also complied with the NWQS during the wet season but changed to noncompliance with the standard when the TP concentration increased substantially during the dry season. The TP concentration was found to be significantly higher $(p$ value $\leq 0.05)$ at the downstream river than the TP concentration at the intake point. The high TP and low SRP concentration indicate that phosphorus concentration mainly consisted of organic phosphorus in the present study. The higher downstream TP concentration further confirms the organic pollutant contribution from the adjacent domestic discharge.

3.3. Cluster Analysis. Figure 7 demonstrates that the water quality in the reservoir can be grouped into three clusters according to the season and the water depth of the reservoir. Cluster 1 and Cluster 2 are mostly made up of sampling stations at depths of $10 \mathrm{~m}$ and $20 \mathrm{~m}$ conducted during the dry season and wet season, respectively, indicating that the dry and wet seasons have an influence on the deeper water column of the reservoir. The surface water quality of the downstream river during the dry (Case 32) and wet (Case 16) seasons was also grouped to Clusters 1 and 2, respectively, as it was influenced by the deeper reservoir water discharged into the river. On the other hand, surface water quality of the reservoir except at Station 5 (Case 13) during the wet season was not influenced by the season where the surface water quality of the Bakun Reservoir during both seasons was categorized as Cluster 3. This phenomenon is the most apparent based on the turbidity and TSS in the reservoir. The surface turbidity and TSS values during the wet and dry seasons were relatively similar with a mean value of $3.02 \mathrm{FNU}$ and $3.66 \mathrm{FNU}$ and $9.0 \mathrm{mg} / \mathrm{L}$ and $8.1 \mathrm{mg} / \mathrm{L}$, respectively, but the turbidity (76.02 FNU versus $133.65 \mathrm{FNU})$ and TSS $(60.7 \mathrm{mg} / \mathrm{L}$ versus $125.5 \mathrm{mg} / \mathrm{L}$ ) values at a depth of $20 \mathrm{~m}$ during the wet season were around two times lower than during the dry season.

\section{Conclusions}

The Bakun hydroelectric reservoir is a thermally stratified reservoir with a temperature gradient of approximately $5^{\circ} \mathrm{C}$ within the thermocline layer. The thickness of the well oxygenated water was around 3-6 $\mathrm{m}$ of the surface water, whereas the oxygen content of most of the water body was below $5 \mathrm{mg} / \mathrm{L}$ or even in hypoxia. The Bakun Reservoir showed signs of organic pollution with high $\mathrm{BOD}_{5}, \mathrm{OKN}$, 
and TP concentrations observed in the reservoir. Acidification was observed in parts of the reservoir, particularly downstream of active logging activities and the Murum hydroelectric dam construction during the wet season. The water quality of the reservoir was influenced by the wet and dry seasons particularly in the deeper water column. SRP and TP concentrations were discovered to be higher during the dry season in the reservoir. This result suggests the necessity of management and conservation of the reservoir to prevent further deterioration in the reservoir's water quality where different water quality parameters should be targeted during different seasons. The present study also demonstrated that the water discharged from the Bakun Reservoir has a great impact on the water quality at the downstream river. The water released from the reservoir decreased the temperature, $\mathrm{DO}$, and $\mathrm{pH}$ of the downstream river whereas turbidity and TSS concentration increased in the downstream river. Nevertheless, the water quality of the downstream river, particularly $\mathrm{BOD}_{5}, \mathrm{OKN}$, and $\mathrm{TP}$ concentrations, was also influenced by adjacent anthropogenic activities such as household wastewater. This result suggests that the downstream river of the Bakun Reservoir was not solely impacted by the reservoir's outflow. Therefore, all factors should be taken into account in decision-making of the management of the downstream river for the health of sensitive aquatic organisms.

\section{Conflicts of Interest}

The authors declare that there are no conflicts of interest regarding the publication of this paper.

\section{Acknowledgments}

The authors appreciate the financial support provided by the Malaysian Ministry of Higher Education through Grant no. FRGS/STWN01(04)/991/2013(32) and the facilities provided by Universiti Malaysia Sarawak.

\section{References}

[1] M. W. Beck, A. H. Claassen, and P. J. Hundt, "Environmental and livelihood impacts of dams: common lessons across development gradients that challenge sustainability," International Journal of River Basin Management, vol. 10, no. 1, pp. 73-92, 2012.

[2] X. Li, S. Dong, Q. Zhao, and S. Liu, "Impacts of Manwan Dam construction on aquatic habitat and community in Middle Reach of Lancang River," Procedia Environmental Sciences, vol. 2, no. 5, pp. 706-712, 2010.

[3] J. Li, S. Dong, S. Liu, Z. Yang, M. Peng, and C. Zhao, "Effects of cascading hydropower dams on the composition, biomass and biological integrity of phytoplankton assemblages in the middle Lancang-Mekong River," Ecological Engineering, vol. 60, pp. 316-324, 2013.

[4] D. D. A. Cunha and L. V. Ferreira, "Impacts of the Belo Monte hydroelectric dam construction on pioneer vegetation formations along the Xingu River, Pará State, Brazil," Revista Brasileira de Botanica, vol. 35, no. 2, pp. 159-167, 2012.
[5] Q. G. Wang, Y. H. Du, Y. Su, and K. Q. Chen, "Environmental impact post-assessment of dam and reservoir projects: a review," Procedia Environmental Sciences, vol. 13, pp. 1439-1443, 2012.

[6] G. L. Wei, Z. F. Yang, B. S. Cui et al., "Impact of dam construction on water quality and water self-purification capacity of the Lancang River, China," Water Resources Management, vol. 23, no. 9, pp. 1763-1780, 2009.

[7] Y. Yi, Z. Yang, and S. Zhang, "Ecological influence of dam construction and river-lake connectivity on migration fish habitat in the Yangtze River basin, China," Procedia Environmental Sciences, vol. 2, no. 5, pp. 1942-1954, 2010.

[8] Q. Lin, "Influence of dams on river ecosystem and its countermeasures," Journal of Water Resource and Protection, vol. 03, no. 01, pp. 60-66, 2011.

[9] W. L. Graf, "Downstream hydrologic and geomorphic effects of large dams on American rivers," Geomorphology, vol. 79, no. 34, pp. 336-360, 2006.

[10] L. Nyanti, T. Y. Ling, and J. Grinang, "Physico-chemical characteristics in the filling phase of Bakun hydroelectric reservoir," vol. 2, pp. 92-101, Sarawak, Malaysia, 2012.

[11] T.-Y. Ling, L. Nyanti, T. Muan, J. Grinang, S.-F. Sim, and A. Mujahid, "Physicochemical parameters of Bakun Reservoir in Belaga, Sarawak, Malaysia, 13 months after reaching full supply level," Sains Malaysiana, vol. 45, no. 2, pp. 157-166, 2016.

[12] S. F. Sim, T. Y. Ling, L. Nyanti, N. Gerunsin, Y. E. Wong, and L. P. Kho, "Assessment of heavy metals in water, sediment, and fishes of a large tropical hydroelectric dam in Sarawak, Malaysia," Journal of Chemistry, vol. 2016, Article ID 8923183, 10 pages, 2016.

[13] L. Nyanti, T. Y. Ling, and T. Muan, "Water quality of Bakun hydroelectric dam reservoir, the construction of Murum dam," ESTEEM Academic Journal, vol. 11, no. 1, pp. 81-88, 2015.

[14] T. Y. Ling, L. Nyanti, and A. S. Masion, "Water quality of rivers that flow into Bakun hydroelectric dam reservoir, Sarawak, Malaysia," ESTEEM Academic Journal, vol. 11, no. 1, pp. 9-16, 2015.

[15] V. Rossel and A. de la Fuente, "Assessing the link between environmental flow, hydropeaking operation and water quality of reservoirs," Ecological Engineering, vol. 85, pp. 26-38, 2015.

[16] T. da Costa Lobato, R. A. Hauser-Davis, T. F. de Oliveira et al., "Categorization of the trophic status of a hydroelectric power plant reservoir in the Brazilian Amazon by statistical analyses and fuzzy approaches," Science of the Total Environment, vol. 506-507, pp. 613-620, 2015.

[17] X. Li, T. Huang, W. Ma, X. Sun, and H. Zhang, "Effects of rainfall patterns on water quality in a stratified reservoir subject to eutrophication: Implications for management," Science of the Total Environment, vol. 521-522, pp. 27-36, 2015.

[18] M. Varol, B. Gökot, A. Bekleyen, and B. Şen, "Spatial and temporal variations in surface water quality of the dam reservoirs in the Tigris River basin, Turkey," Catena, vol. 92, pp. 11-21, 2012.

[19] Y. Zhang, Z. Wu, M. Liu et al., "Dissolved oxygen stratification and response to thermal structure and long-term climate change in a large and deep subtropical reservoir (Lake Qiandaohu, China)," Water Research, vol. 75, pp. 249-258, 2015.

[20] T. Y. Ling, T. Z. E. Lee, and L. Nyanti, "Phosphorus in batang ai hydroelectric dam Reservoir, Sarawak, Malaysia," World Applied Sciences Journal, vol. 28, no. 10, pp. 1348-1354, 2013.

[21] P. McCully, "Rivers no more: the environmental effects of dams," in Silenced Rivers: The Ecology and Politics of Large Dams, P. McCully, Ed., pp. 29-64, Zed Books, London, UK, 1996. 
[22] T.-Y. Ling, C.-L. Soo, T. L.-E. Heng, L. Nyanti, S.-F. Sim, and J. Grinang, "Physicochemical characteristics of river water downstream of a large tropical hydroelectric dam," Journal of Chemistry, vol. 2016, Article ID 7895234, 2016.

[23] D. Jenkins, J. J. Connors, and A. E. Greenberg, Standard Methods for the Examination of Water and Wastewater, American Public Health Association, Washington, Wash, D.C, USA, 21st edition edition, 205.

[24] Hach, Hach Water Analysis Handbook, Hach Company, USA, 2015.

[25] D. F. Goerlitz and E. Brown, "Methods for analysis of organic substances in water," in Techniques of Water-Resources Investigations of The United States Geological Survey, R. L. Wershaw, M. J. Fishman, R. R. Grabbe, and L. E. Lowe, Eds., pp. 1-40, U. S. Geological Survey, United States, 1972.

[26] Y. Hayami, K. Ohmori, K. Yoshino, and Y. S. Garno, “Observation of anoxic water mass in a tropical reservoir: the cirata reservoir in java, Indonesia," Limnology, vol. 9, no. 1, pp. 81-87, 2008.

[27] C. Ariyadej, P. Tansakul, and R. Tansakul, "Variation of phytoplankton biomass as chlorophyll a in banglang reservoir, yala province," Songklanakarin Journal of Science and Technology, vol. 30, no. 2, pp. 159-166, 2008.

[28] T.-Y. Ling, L. Nyanti, C.-K. Leong, and Y.-M. Wong, "Comparison of water quality at different locations at Batang Ai Reservoir, Sarawak, Malaysia," World Applied Sciences Journal, vol. 26, no. 11, pp. 1473-1481, 2013.

[29] G. B. Sahoo and D. Luketina, "Modeling of bubble plume design and oxygen transfer for reservoir restoration," Water Research, vol. 37, no. 2, pp. 393-401, 2003.

[30] Y. Zhou, D. R. Obenour, D. Scavia, T. H. Johengen, and A. M. Michalak, "Spatial and temporal trends in Lake Erie hypoxia, 1987-2007," Environmental Science and Technology, vol. 47, no. 2, pp. 899-905, 2013.

[31] T. Y. Ling, D. P. Debbie, N. Lee, I. Norhadi, and J. J. E. Justin, "Water quality at Batang Ai Hydroelectric Reservoir (Sarawak, Malaysia) and implications for aquaculture," vol. 2, pp. 23-30, 2012.

[32] Department of Environment, Malaysia Environmental Quality Report 2014, Department of Environment, Kuala Lumpur, Malaysia, 2015.

[33] T. R. Fisher, L. W. Harding Jr., D. W. Stanley, and L. G. Ward, "Phytoplankton, nutrients, and turbidity in the Chesapeake, Delaware, and Hudson estuaries," Estuarine, Coastal and Shelf Science, vol. 27, no. 1, pp. 61-93, 1988.

[34] P.-P. Shen, G. Li, L.-M. Huang, J.-L. Zhang, and Y.-H. Tan, "Spatio-temporal variability of phytoplankton assemblages in the Pearl River estuary, with special reference to the influence of turbidity and temperature," Continental Shelf Research, vol. 31, no. 16, pp. 1672-1681, 2011.

[35] L. Nyanti, K. M. Hiii, A. Sow, I. Norhadi, and T. Y. Ling, "Impacts of aquaculture at different depths and distances from cage culture sites in batang Ai hydroelectric dam reservoir, Sarawak, Malaysia," World Applied Sciences Journal, vol. 19, no. 4, pp. 451456, 2012. 

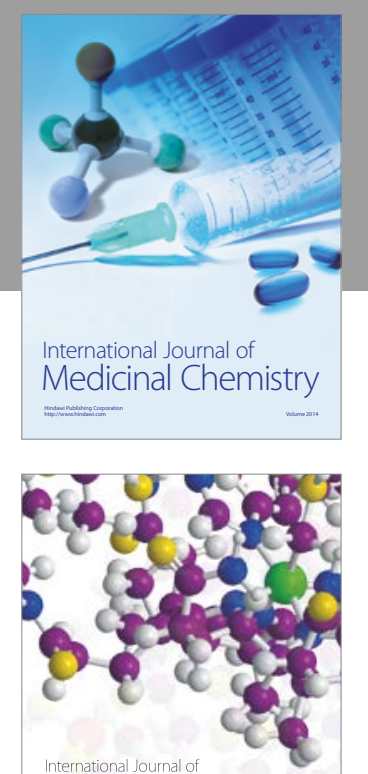

Carbohydrate Chemistry

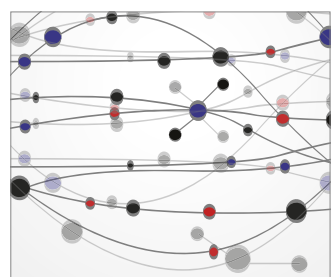

The Scientific World Journal
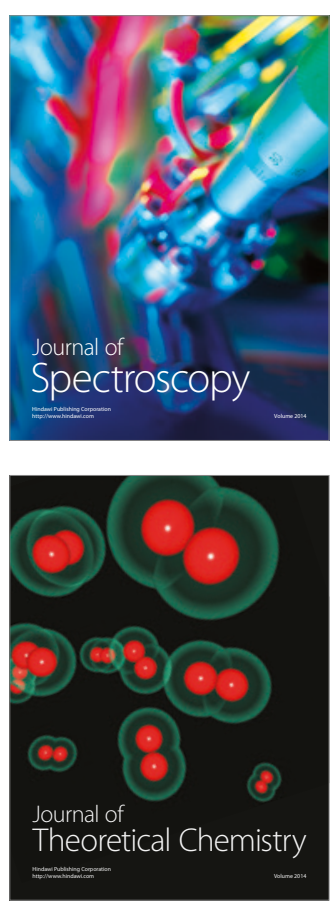
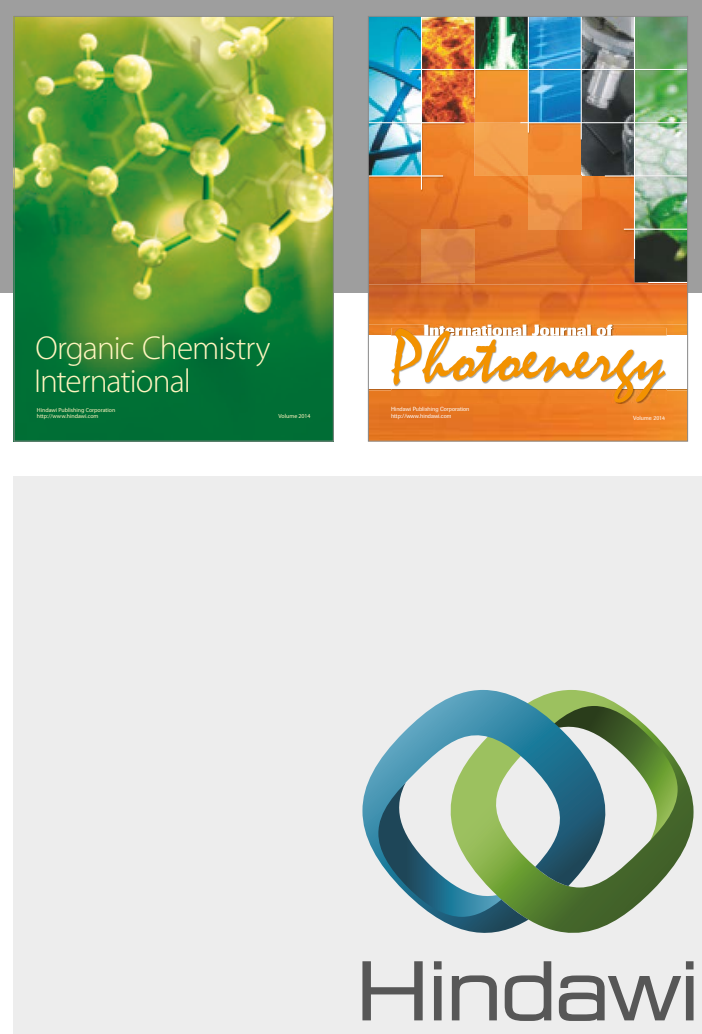

Submit your manuscripts at

https://www.hindawi.com

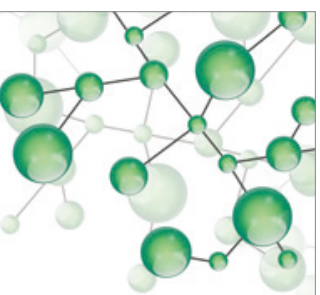

International Journal of

Inorganic Chemistry

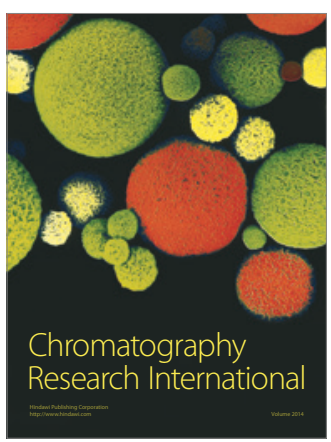

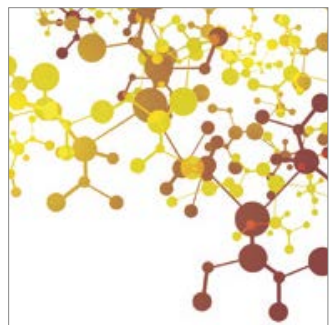

Applied Chemistry
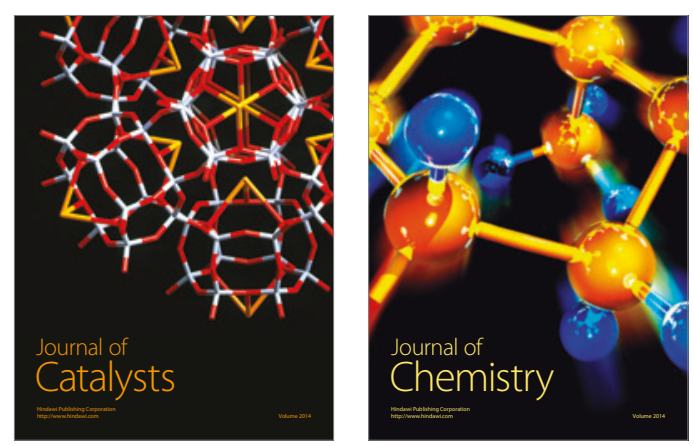
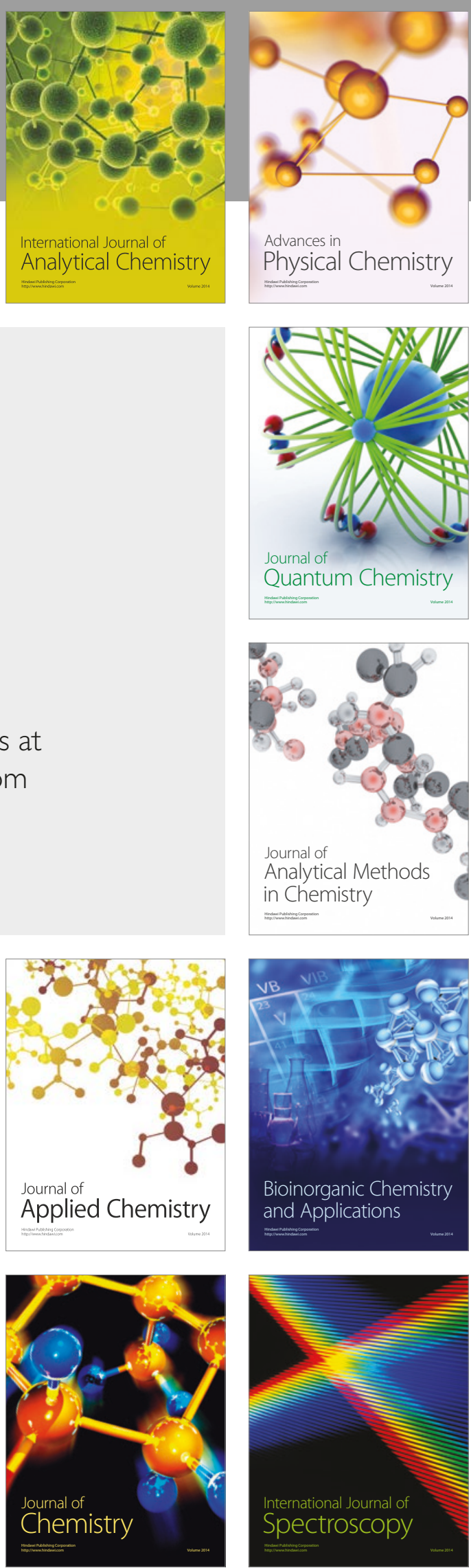